\title{
Mediterranean jellyfish as novel food: effects of thermal processing on antioxidant, phenolic, and protein contents
}

\author{
Antonella Leone ${ }^{1,4}\left(\mathbb{D} \cdot\right.$ Raffaella Marina Lecci $^{1} \cdot$ Giacomo Milisenda $^{2,3} \cdot$ Stefano Piraino ${ }^{2,4}$
}

Received: 24 September 2018 / Revised: 14 January 2019 / Accepted: 24 January 2019 / Published online: 16 March 2019

(c) The Author(s) 2019

\begin{abstract}
Fishery, market and consumption of edible jellyfish are currently limited in western countries by the lack of market demand for jellyfish products and the absence of processing technologies adequate to the western market safety standards. The development of technology-driven processing protocols may be key to comply with rigorous food safety rules, overcome the lack of tradition and revert the neophobic perception of jellyfish as food. We show thermal treatment $\left(100{ }^{\circ} \mathrm{C}, 10 \mathrm{~min}\right) \mathrm{can}$ be used as a first stabilization step on three common Mediterranean jellyfish, the scyphomedusae Aurelia coerulea, Cotylorhiza tuberculata, Rhizostoma pulmo, differently affecting protein and phenolic contents of their main body parts. The antioxidant activity was assessed in thermally treated and untreated samples, as related to the functional and health value of the food. Heat treatment had mild effect on protein and phenolic contents and on antioxidant activity. The jellyfish Rhizostoma pulmo, showed the better performance after thermal treatment.
\end{abstract}

Keywords Edible jellyfish $\cdot$ Marine scyphozoans $\cdot$ Novel food $\cdot$ Antioxidant foods $\cdot$ Thermal processing $\cdot$ Antioxidant activity

Electronic supplementary material The online version of this article (https://doi.org/10.1007/s00217-019-03248-6) contains supplementary material, which is available to authorized users.

Antonella Leone

antonella.leone@ispa.cnr.it

Raffaella Marina Lecci

raffaella.lecci@ispa.cnr.it

Giacomo Milisenda

giacomo.milisenda@gmail.com

Stefano Piraino

stefano.piraino@unisalento.it

1 Consiglio Nazionale delle Ricerche, Istituto di Scienze delle Produzioni Alimentari, Unità di Lecce (CNR-ISPA), Via Monteroni, 73100 Lecce, Italy

2 Dipartimento di Scienze e Tecnologie Biologiche ed Ambientali (DiSTeBA), University of Salento, Lecce, Italy

3 Stazione Zoologica Anton Dohrn, Centro Interdipartimentale della Sicilia, Lungomare Cristoforo Colombo (ex complesso Roosevelt), 90142 Palermo, PA, Italy

4 Consorzio Nazionale Interuniversitario per le Scienze del Mare (CoNISMa), Local Unit of Lecce, Via Monteroni, 73100 Lecce, Italy

$\begin{array}{ll}\text { Abbreviations } & \\ \text { AA } & \text { Antioxidant activity } \\ \text { ABTS } & \text { 2,20-azinobis(3-ethylben-zothiazoline- } \\ & \text { 6-sulfonic acid)diammonium salt } \\ \text { BSA } & \text { Bovine serum albumin } \\ \text { GAE } & \text { Gallic acid equivalents } \\ \text { TE } & \text { Trolox equivalents } \\ \text { Trolox } & \text { 6-hydroxy-2,5,7,8-tetramethylchroman- } \\ & \text { 2-carboxylic acid } \\ \text { TEAC } & \text { Trolox equivalent antioxidant capacity } \\ \text { WB } & \text { Whole fresh jellyfish } \\ \text { OA } & \text { Oral arms } \\ \text { U } & \text { Umbrella } \\ \text { A. coerulea } & \text { Aurelia coerulea } \\ \text { C. tuberculata } & \text { Cotylorhiza tuberculata } \\ \text { R. pulmo } & \text { Rhizostoma pulmo }\end{array}$

\section{Introduction}

A growing number of reports focuses on world jellyfish fishery and on the perspective for a wide use of jellyfish as food (herein jellyfish is referred as the pelagic phase of marine cnidarians belonging to the class Scyphozoa) [1]. Edible jellyfish harvesting and consumption is popular in China 
[2] and across the whole South East Asia [3, 4], based on the exploitation of several jellyfish species belonging to the order Rhizostomae characterized by the considerable stiffness and consistency of their extracellular proteinaceous mesoglea. This makes species such as Rhopilema esculentum, Catostylus mosaicus, Nemopilema nomurai, Stomolophus spp. particularly appreciated as valuable and healthy food following a long-standing tradition.

Recently, jellyfish fisheries successfully developed in the Americas with new jellyfish species being exported to the main consumer countries [2, 5-7]. The Food and Agriculture Organization of the United Nations (FAO) statistics [8] on global production of all edible jellyfish products (live, fresh, chilled, frozen, dried, salted or in brine) in the period 2011-2015 was estimated around 10,000-17,000 tons/year with a growing business trend of about 20-100 million USD, and a stable market value at about $2500 \mathrm{USD} /$ ton [8]. However, the FAO statistics resulted clearly underestimating in case of jellyfish, indeed, the China Fishery Statistical Yearbook of 2017 [9] reported near 280,000 tons of edible jellyfish production in China only, in the years 2015-2016. Fishery, market and consumption of jellyfish are currently limited in western countries by the lack of market demand for jellyfish products and the absence of processing technologies adequate to the western market safety standards. In Europe, the lack of tradition for edible jellyfish and the presence of strict food safety criteria made the official market of jellyfish food still absent. Recently, the new European regulation on novel food [10] together with the biochemical characterization and identification of bioactive properties of some Mediterranean jellyfish species [11-13] paved the way to the potential use of western jellyfish as food. Major gaps to the development of the commercial exploitation of jellyfish in western countries include the lack of knowledge on fishery methods, handling and first-stabilization protocols. Secondly, jellyfish as food is not familiar to most of western consumers and it is negatively perceived. Therefore, new opportunities for expanding jellyfish food uses in western countries will rely on the development of new processing technologies and of market demand, which in turn will depend on increased knowledge of jellyfish as food raw material and from its public perception, respectively.

Edible jellyfish are poorly characterized for their nutritional qualities, and the different methodologies used make still difficult to compare different species and products.

The entirety of marketed jellyfish products (Fig. 1) is made by the traditional Chinese processing method based on alum-salt dehydration, and the jellyfish products are typically consumed after desalting and rehydration in salads or after cooking $[4,6,14-16]$. Alum, as brine component, reduces $\mathrm{pH}$, acts as an antiseptic and maintains the firm texture by precipitating proteins [4]. This traditional method preserve jellyfish leading to a typical product responding to
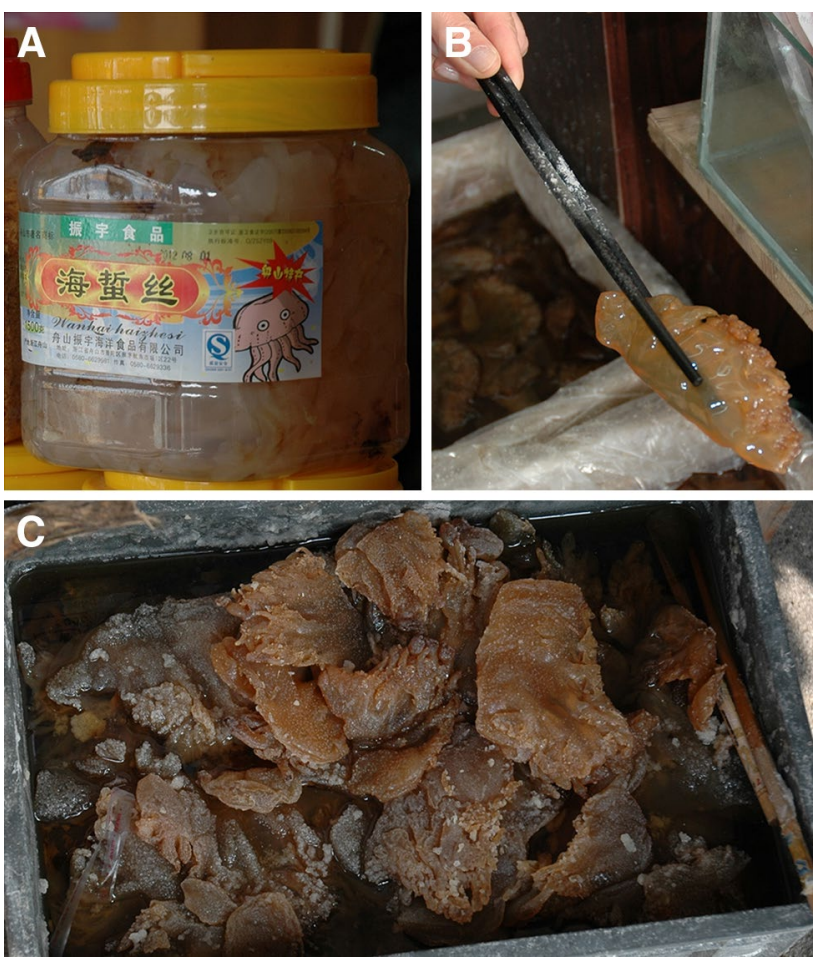

Fig. 1 Edible jellyfish products marketed in local markets in China. The jellyfish are processed by the traditional Chinese method based on alum-salt dehydration and sold as canned in brine product (a), semi-dried (b) or dry-salted (c). Photos: Antonella Leone

the sensory parameters (color, texture, and overall acceptability) requested by Asiatic consumers [16]. However, edible jellyfish tissues treated with alum may retain alarming amounts of aluminum [17-19], which is known to be responsible of a number of negative effects on human health, including Alzheimer's disease [18].

No alternative processing method is officially adopted worldwide for dehydration of edible jellyfish, although the microbiological stability, the sensory and chemical analysis of a microwave cooked Catostylus tagi umbrella was recently investigated [20]. Due to the high moisture and rapid perishability of the raw material, a quick stabilizing process is required to drastically reduce the water content and water activity and to maintain tissue firmness, which is related to structural changes of collagen, the dominant protein component of jellyfish. In this framework, denaturation is an irreversible kinetic process, which leads collagen molecules to lose their structural organization, resulting in random coiled polymeric chains. Denaturation can be promoted by chemical or thermal-treatments [21] and, regardless of the underlying molecular mechanisms, heatdenaturation causes collagen to both shrink and dehydrate [22]. Thermal processing is usually applied to raw food prior the consumption or during processing to kill or inactivate bacteria, increase the shelf-life, or improve organoleptic 
characteristics and sensory appeal of the food. High-protein foods are often processed by heat-based methods [23] and heat treatment of protein-rich, solid raw material is largely studied in food processing [24, 25]. In general, thermal treatment induces changes in the 3D structure of food proteins, including color, tenderness, and gelation modifications. So far, thermal processing has not yet been considered for fresh edible jellyfish, and there is no available information on processing methods for Mediterranean jellyfish.

Due the growing awareness of health-related benefits associated to functional food consumption, a successful innovation in food processing technology aim to preserve the healthy properties of the foods. Jellyfish is regarded as healthy food in the Chinese cuisine, traditional Chinese medicine and food therapy $[4,14,26]$; however, the health impact of this traditional food has not yet been adequately investigated by modern quantitative and rigorous scientific research.

Several peptides from protein foods or ingredients, including seafood by-products [27] and jellyfish [12, 13, 28-35] have been found to possess antioxidant capacity and they can contribute to the endogenous antioxidant capacity of foods. Proteins also have excellent potential as antioxidant additives in foods because they can inhibit lipid oxidation through multiple pathways including inactivation of reactive oxygen species, scavenging free radicals, chelation of prooxidative transition metals, reduction of hydroperoxides, and alteration of the physical properties of food systems [36, 37]. Similarly, although not considered nutrients in the classical sense, other compounds such as phenols, mainly of plant origin, show a plethora of biological activities, including a strong antioxidant ability [38-40]. They have healthpromoting properties, which involve different and complex action mechanisms, often mediated by their antioxidant ability $[38,41]$. In recent years, a greater emphasis has been placed on the link between oxidative stresses in human cells, the pathogenesis of diseases and their prevention by natural antioxidant-rich diets. Edible jellyfish tissues are known to possess high antioxidant activity [12, 30, 32, 35, 42, 43]. Additionally, some Mediterranean jellyfish contain endosymbiotic zooxanthellae producing phenols, proteins, and other antioxidant compounds [13].

Jellyfish can belong to very different species, but they all share the common feature to have special stinging cells, the cnidocytes, each characterized by a subcellular organelle (the cnidocyst) containing species-specific toxins. Cnidarian venoms and toxins are heat labile at temperatures safe for treatments on humans after jellyfish stings, as demonstrated by the beneficial effects of local heat treatments in the most clinical studies $[44,45]$. In addition, no allergic reaction was found in a preliminary trial with raw and boiled Catostylus tagi in seafood allergic individuals [46]. For this reason, thermal treatment can be a strategic choice for jellyfish processing able to overcome the toxicity issues related to such novel food raw material.

By increasing knowledge about raw material treatments and jellyfish as safe and healthy food, it is possible to foresee an increased use of jellyfish as food, with beneficial effects on coastal sea-based economies through releasing fishery, maritime tourism and other human activities from impacts of jellyfish blooms and, at the same time, providing a new source of income to fishermen.

To uncover the potential of Mediterranean jellyfish and their components for nutraceutical, nutricosmetic, and food uses, we investigated the protein and phenolic contents of different body parts (bell and oral arms) of three Mediterranean jellyfish, Aurelia coerulea, Cotylorhiza tuberculata and Rhizostoma pulmo, focusing on the observed changes following heat treatment as a viable first stage of the stabilization process.

A first screening of the functional properties of Mediterranean jellyfish compounds was also carried out by detecting changes in antioxidant activity induced by heat treatment as novel putative food processing step.

\section{Materials and methods}

\section{Chemicals}

All chemicals used were of analytical grade. Methanol, ethanol and acetic acid were purchased from Merck (Darmstadt, Germany); potassium persulfate (dipotassium peroxodisulfate), 6-hydroxy-2,5,7,8-tetramethylchroman-2-carboxylic acid (Trolox) were purchased from Hoffman-La Roche. 2,20-azinobis (3-ethylben-zothiazoline-6-sulfonic acid) diammonium salt (ABTS), gallic acid, Folin-Ciocalteu's phenol reagent (product F9252), were purchased from Sigma-Aldrich.

\section{Jellyfish collection}

Specimens of three scyphozoan jellyfish species, namely Aurelia coerulea von Lendenfeld 1884 (order Semaeostomeae) [47], Cotylorhiza tuberculata, Macrì 1778, and Rhizostoma pulmo, Macrì 1778 (order Rhizostomeae), were collected along the Apulian coasts of Italy (Adriatic Sea, Ionian Sea) during 2012-2017 (Fig. 2) by means of a nylon landing net with $3.5 \mathrm{~cm}$ mesh size, from an open type motor boat, and stored in refrigerated seawater for a maximum of $2 \mathrm{~h}$. Jellyfish were transported in refrigerated $\left(5 \pm 2{ }^{\circ} \mathrm{C}\right)$ seawater holding tanks, and treated in the lab within $2-3 \mathrm{~h}$ after collection. Biometric measures, i.e., bell diameter and total wet weight, were taken to the nearest $\mathrm{mm}$ and gram by a caliper and a weight scale. Immediately after measurement, 10-12 specimens of each species were frozen in liquid 


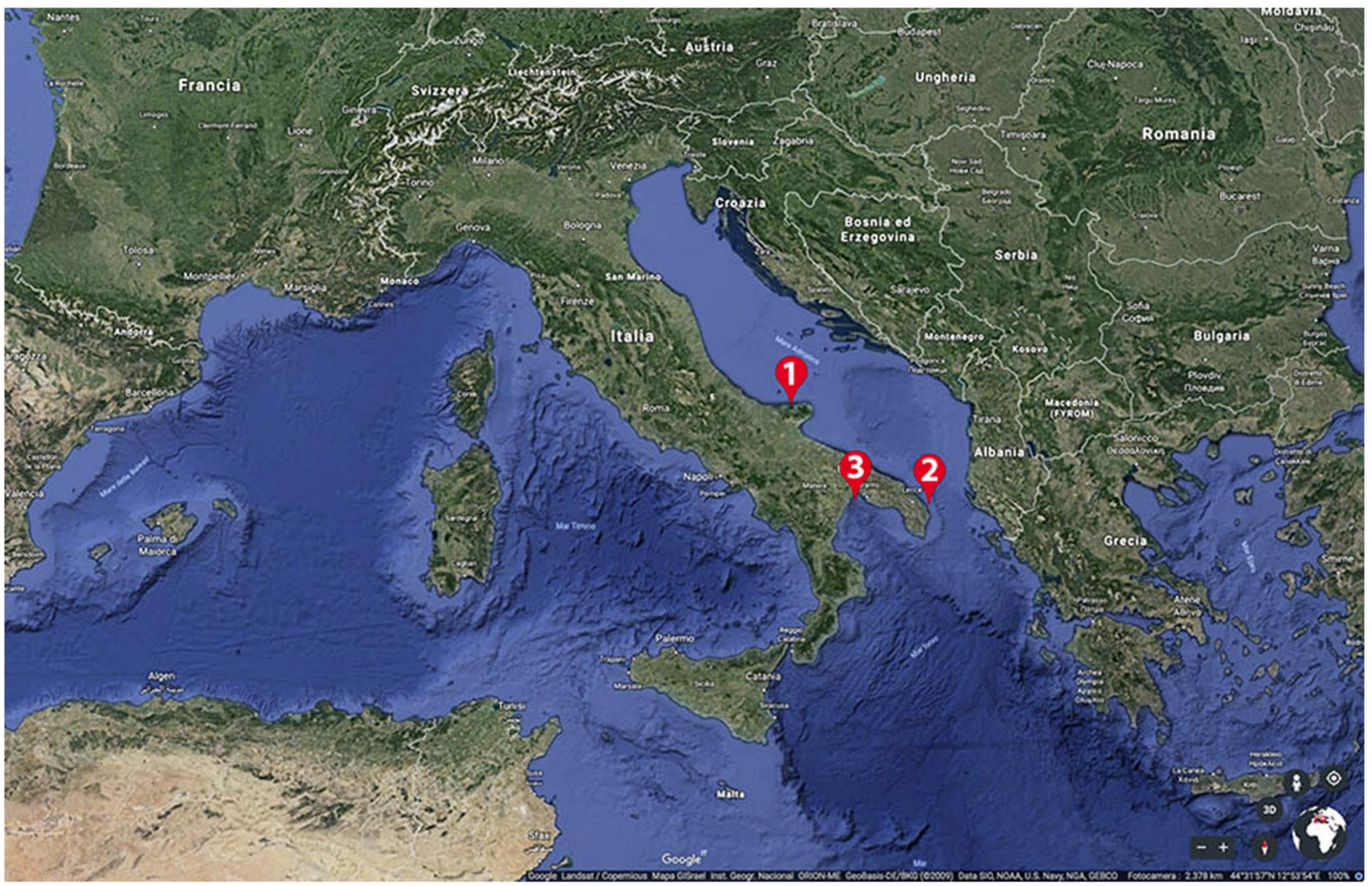

Fig. 2 Sampling sites in the Mediterranean Sea (summers 2012-2017). Aurelia coerulea was sampled at Varano Lake, Adriatic Sea (1); Cotylorhiza tuberculata and Rhizostoma pulmo along the Salento Peninsula coastline, Ionian and South Adriatic Seas (2 and 3)

nitrogen and freeze-dried for 4 days at $-55^{\circ} \mathrm{C}$ in a chamber pressure of 0.110 mbar in a freeze dryer (Freezone 4.5L Dry System, Labconco Co. Thermo Scientific) to calculate the dry weight and total protein content (Table 1). Other samples were kept as fresh material and immediately subjected to thermal treatment as described below.

\section{Thermal treatment and biochemical analyses}

To test the temperature effect, 5-7 specimens of comparable size for each species were subjected to thermal processing either as fresh whole jellyfish specimens (WB), or separately on their two main body components, i.e., the bellshaped umbrella $(\mathrm{U})$, and the jellyfish mouth parts, also called manubrium and oral arms (OA) (Figs. 3, 4, 5). Due to the different sizes of the diverse jellyfish species and individuals, homogeneous samples from larger sized jellyfish were obtained by sectioning specimens as shown in Fig. 5. Each sample was heat-treated in PBS pH 7.4 (Phosphate Buffered Saline, $0.01 \mathrm{M} \mathrm{Na}_{2} \mathrm{HPO}_{4}, 0.15 \mathrm{M} \mathrm{NaCl}$, using Sodium Phosphate Monobasic $\mathrm{NaH}_{2} \mathrm{PO}_{4}{ }^{*} \mathrm{H}_{2} \mathrm{O}$ and dibasic $\left.\mathrm{Na}_{2} \mathrm{HPO}_{4} * 7 \mathrm{H}_{2} \mathrm{O}\right)$, in a ratio $1: 2(\mathrm{w} / \mathrm{v})$ at $100{ }^{\circ} \mathrm{C}$ for $10 \mathrm{~min}$
Table 1 Biometric measures, fresh and dry weight and protein content in samples of the three jellyfish species $A$. coerulea, $C$. tuberculata and R. pulmo

\begin{tabular}{lccc}
\hline & Aurelia coerulea & $\begin{array}{l}\text { Cotylorhiza tuber } \\
\text { culata }\end{array}$ & Rhizostoma pulmo \\
\hline Umbrella diameter (cm) & $15.5 \pm 2.9$ & $17.5 \pm 2.3$ & $18.8 \pm 4.2$ \\
Ratio FW/diameter & $12.5 \pm 7.1$ & $22.2 \pm 9.9$ & $31.8 \pm 12.2$ \\
Fresh weight (g) & $240 \pm 123$ & $625 \pm 153$ & $850 \pm 221$ \\
Dry weight (\% of f.w) & $2.80 \pm 0.3$ & $8.31 \pm 2.68$ & $5.05 \pm 1.03$ \\
Total protein content in fresh & $2.54 \pm 0.5$ & $1.6 \pm 0.9$ & $2.27 \pm 0.9$ \\
samples (mg/g of f.w.) & & & \\
\hline
\end{tabular}

Data are expressed as means \pm SD $(10<n<12)$ 

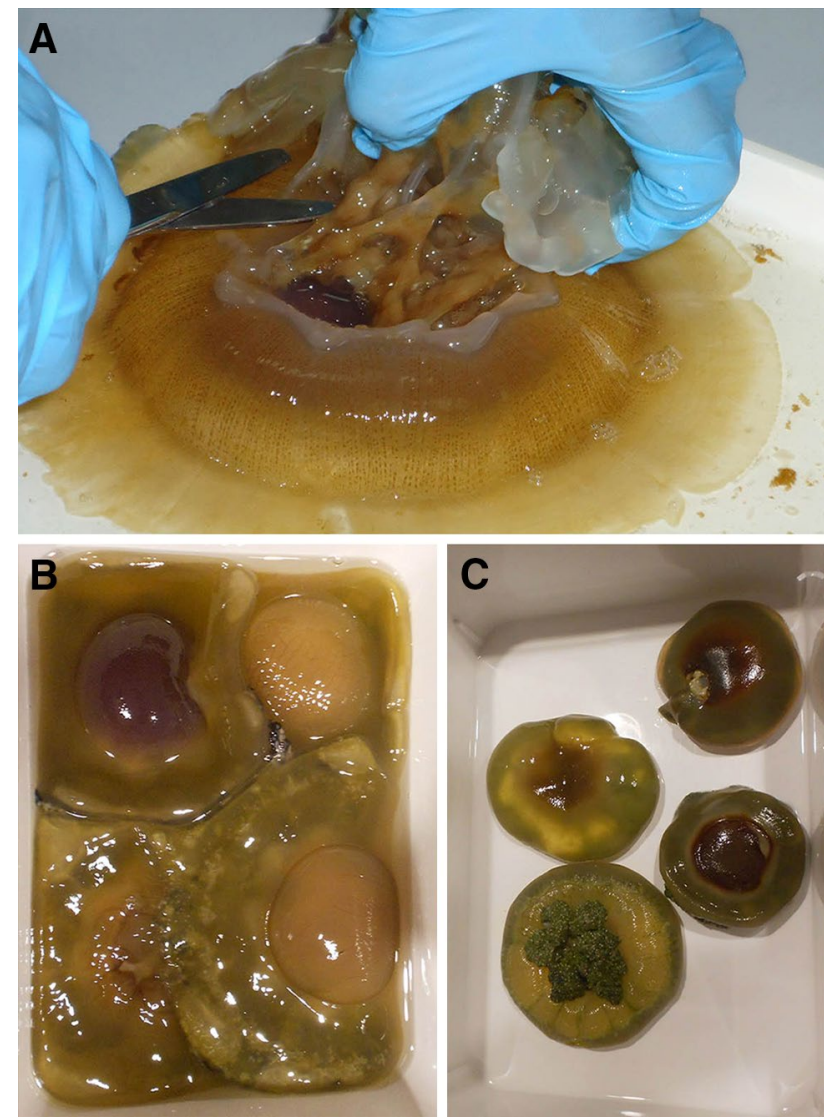

Fig. 3 Processing of Cotylorhiza tuberculata specimens in lab. a Separation of oral arms (OA) and umbrella (U); $\mathbf{b}$ jellyfish treated at $25^{\circ} \mathrm{C}$ for $10 \mathrm{~min}$; c jellyfish treated at $100{ }^{\circ} \mathrm{C}$ for $10 \mathrm{~min}$

(HT100). The thermal treatment was performed using glass beaker containing the PBS, closed with aluminum foil and doubled Parafilm ${ }^{\circledR}$, into a little bigger container full of bidistilled $\mathrm{H}_{2} \mathrm{O}$, placed on a lab hot plate with magnetic stirrer. The bidistilled $\mathrm{H}_{2} \mathrm{O}$ was stirred to allow constant temperature. When the temperature reached $100{ }^{\circ} \mathrm{C}$ in both containers the JF sample was added. By many trials we have found that the temperature only lowered in the first minute to go back up to $99-100{ }^{\circ} \mathrm{C}$ for the rest of the time $(10 \mathrm{~min})$. In this way, the dispersion was made negligible. As control treatment (CT), an equivalent number of whole or divided jellyfish specimens in the same conditions as above were processed at $25 \pm 1{ }^{\circ} \mathrm{C}$. The same apparatus was placed in a growth room $(3 \times 2.5$ meters $)$ with controlled temperature and humidity by a three-phase electric panel (Plus1000THR, Pego, Pego srl, Occhiobello, Padova) with the temperature set at $25.0^{\circ} \mathrm{C}$. The experiment was performed when PBS temperature was stable at $25{ }^{\circ} \mathrm{C} \pm 1{ }^{\circ} \mathrm{C}$. A test experiment using water bath with distilled water was also performed. Aside from the thermal-treatments, all samples were kept in an ice bath before analysis.
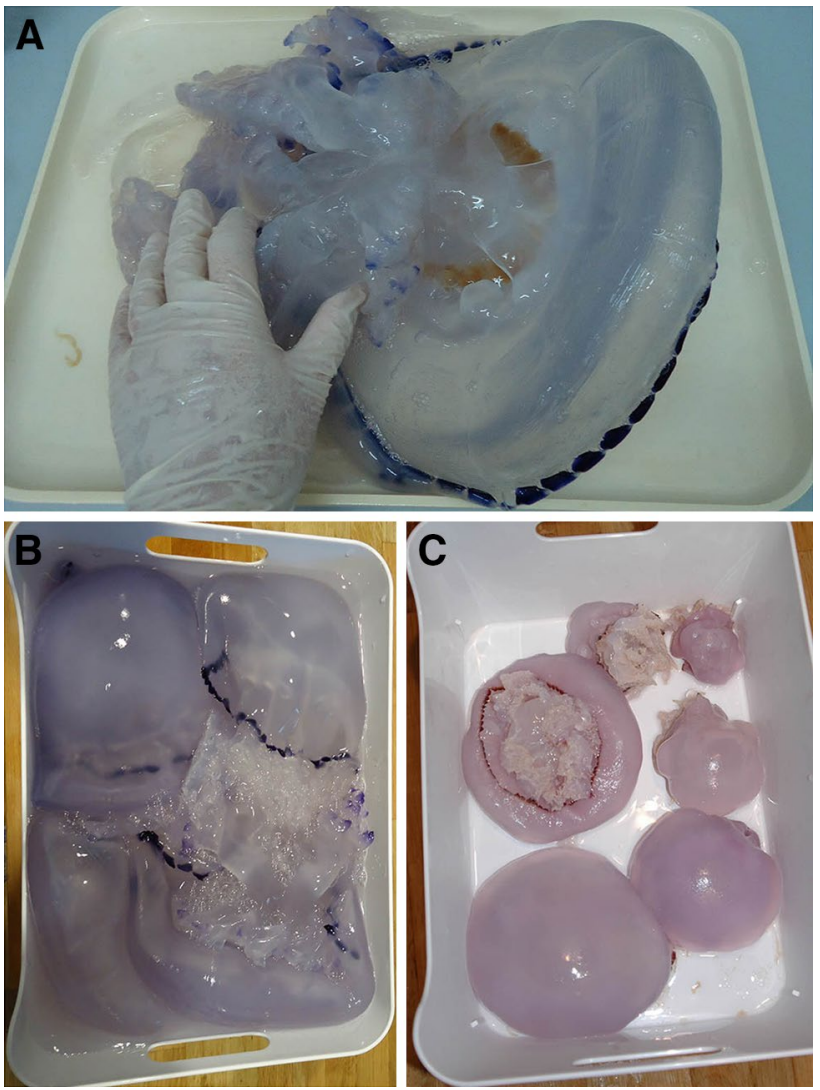

Fig. 4 Processing of Rhizostoma pulmo specimens in lab. a Separation of oral arms (OA) and umbrella (U); b jellyfish treated at $25^{\circ} \mathrm{C}$ for $10 \mathrm{~min}$; c jellyfish treated at $100{ }^{\circ} \mathrm{C}$ for $10 \mathrm{~min}$

Soon after each sample treatment, the PBS medium was separated from the jellyfish specimens, the volumes were measured and the possible content of soluble proteins, total phenols and antioxidant activity were evaluated in the PBS bath. Whole jellyfish (WB), umbrella (U) and oral arms (OA) were drained and separately homogenized by Polytron Homogenizer (Kinematica GmbH, Switzerland) using 7 pulses of $30 \mathrm{~s}$ each. Jellyfish homogenates were centrifuged at $2800 \times g$ for $25 \mathrm{~min}$ at $4{ }^{\circ} \mathrm{C}$ in a Allegra ${ }^{\circledR} \mathrm{X}-15 \mathrm{R}$ centrifuge (Beckman Coulter, Indianapolis, US). Both the supernatants and pellets were evaluated for protein and phenolic contents, and for the antioxidant activity in each sample. After the volume evaluation (Table S1), the biochemical assays were performed on aliquots collected before and after the centrifugation. Supernatants were assayed directly or after dilution if necessary, the pellets were diluted again in PBS and further homogenized, on ice, by a Thomas tissue grinder consisting of piston-type Teflon ${ }^{\circledR}$ pestle with stainless steel shaft and grinding vessel of borosilicate glass. Volumes and dilutions were accurately annotated to correctly measure the protein and phenol concentration. 
Fig. 5 Scheme of jellyfish samples. Small size jellyfish specimens were processed either as whole organisms or umbrella and oral arms, with these two body parts separated and processed without further sectioning. Large size jellyfish were considered as homogeneous specimens taken as longitudinal sections (quarters or multiple of quarters) of the whole jellyfish (including umbrella + oral arms) or as sections (quarters or multiple of quarters) of umbrellas or sections of oral arms only

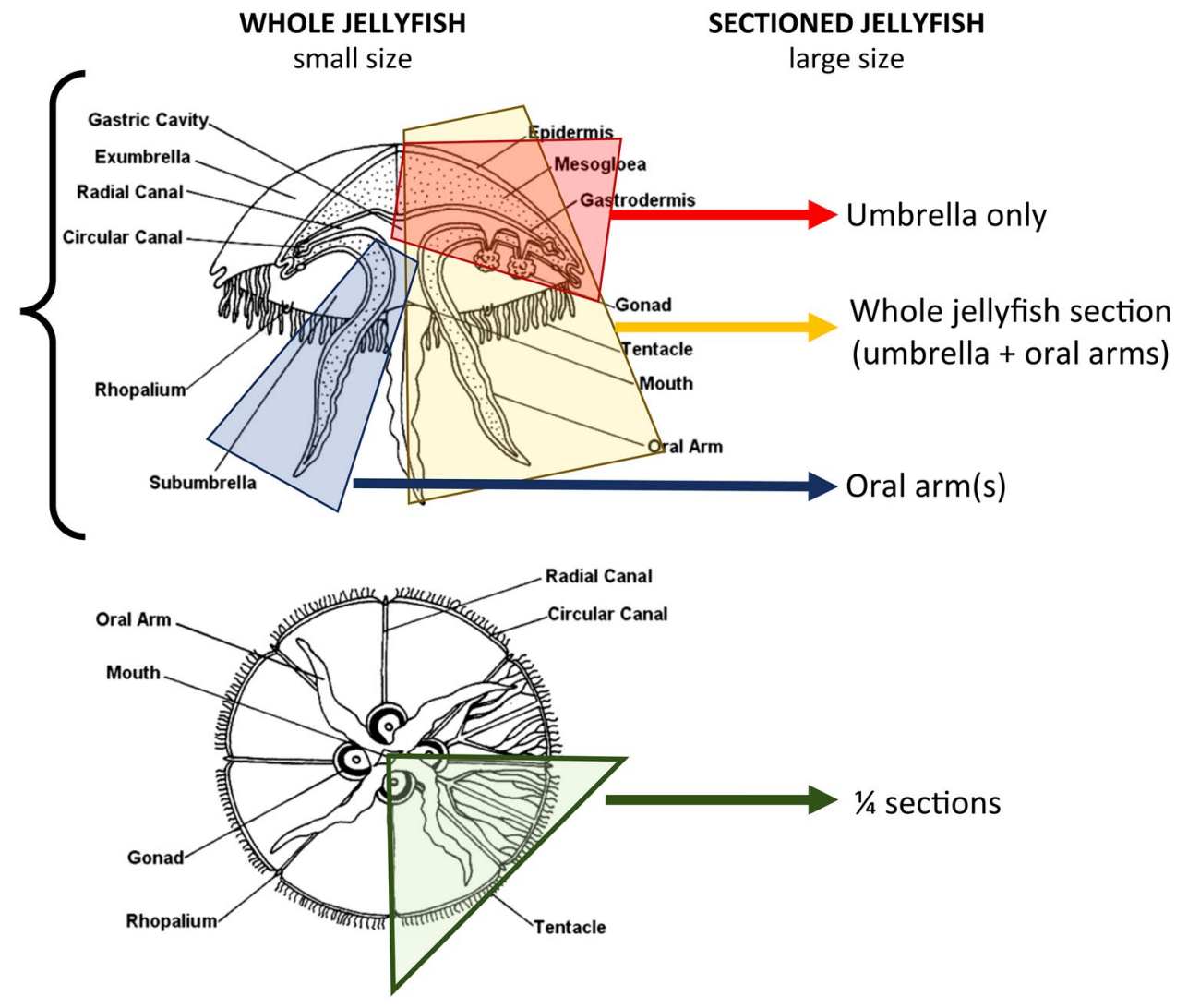

\section{Protein concentration}

Protein content was estimated by Bradford assay [48] using bovine serum albumin (BSA) as standard.

\section{Phenolic content}

The total content of phenols was determined by a modified Folin-Ciocalteau colorimetric method [49]. Samples $(100 \mu \mathrm{L})$ were mixed with $500 \mu \mathrm{L}$ of Folin-Ciocalteu's phenol reagent and with $500 \mu \mathrm{L}$ of $7.5 \%$ (w/v) sodium carbonate $\left(\mathrm{Na}_{2} \mathrm{CO}_{3}\right)$. After $2 \mathrm{~h}$, at room temperature in the dark, the absorbance was spectrophotometrically measured at $760 \mathrm{~nm}$. Gallic acid diluted in PBS, ranging from 25 to $200 \mu \mathrm{g} / \mathrm{mL}$, was used as standard. The results were expressed as gallic acid equivalents (GAE) per gram of sample.

\section{In vitro antioxidant activity}

The total antioxidant activity was determined spectrophotometrically using the Trolox Equivalent Antioxidant Capacity (TEAC) method, as described in [13], using the radical cation $\mathrm{ABTS}^{\bullet+}$. This assay measures the relative ability of antioxidant to scavenge the ABTS generated in aqueous phase, as compared with a Trolox (water soluble vitamin $\mathrm{E}$ analogue) standard. Ten microliters of each jellyfish homogenate were essayed into $1 \mathrm{~mL}$ of the reaction mixture. Same volumes of PBS were used as control. A Trolox calibration curve in a range of $2.5-20 \mu \mathrm{M}$ was prepared and the antioxidant content of the samples was calculated as decrease in absorbance at $734 \mathrm{~nm}$ after a fixed time period of $6 \mathrm{~min}$. Results were expressed as nmol of Trolox equivalents per gram of sample or per mg of contained proteins or phenols.

\section{Statistical analysis}

Randomization of $t$ test by bootstrapping procedure was used to evidence significant differences in the amount of (a) protein contents; (b) phenol contents, and (c) antioxidant activity between the two temperature treatments $\left(25^{\circ} \mathrm{C}\right.$ and $\left.100^{\circ} \mathrm{C}\right)$. Moreover, randomization of $t$-test was chosen to cope with possible problem of non-normality and heteroscedasticity of data. The test was repeated for all the three jellyfish species, and the comparison were made both in the whole jellyfish tissue, and in the separated body parts (umbrella and oral arms). Statistical analysis was conducted with the software R (R Core Team 2017) [50], using the package "boot" [51, 52]. 


\section{Results and discussion}

\section{Heat treatment}

To evaluate the effect of a thermal-based stabilization step for the potential exploitation of three Mediterranean jellyfish species as human food resource, jellyfish were processed as fresh material and subjected to HT100 $\left(100{ }^{\circ} \mathrm{C}\right.$ for $10 \mathrm{~min}$ ) in PBS pH 7.4. Boiled jellyfish showed a timedependent body shrinkage and a reduction of their aqueous volume confirming the dehydration effect of heat treatment on proteinaceous food components. In our experiments, HT100 in both distilled water and PBS, induced a timedependent biomass volume reduction with a weight loss up to $18 \%( \pm 1 \%)$ of the initial fresh weight (Figs. 3c, 4c). No swelling was detected in control samples treated at $25{ }^{\circ} \mathrm{C}$ for $10 \mathrm{~min}$ (Figs. 3b, 4b). For all samples the data were referred to the respective initial fresh weight.

\section{Effect of heat treatment on protein content}

Biometric data, including bell diameter and fresh and dry weight, and total protein content of the investigated populations of the jellyfish Aurelia coerulea, Cotylorhiza tuberculata, and Rhizostoma pulmo are shown in Table 1.

The protein content of the whole jellyfish (WB), the umbrella (U) and oral arms (OA) were evaluated for the three jellyfish species (Fig. 6A-A, $\mathrm{B}-\mathrm{B} 1$ and $\mathrm{C}-\mathrm{C}_{1}$ ) exposed to the thermal treatment (HT100), which is denaturing temperature for protein, including marine collagen $[21,53]$.

Despite its reduced sensitivity for collagen protein, the classical Bradford assay method was used to allow a better comparison between differently treated and not treated samples. Overall, A. coerulea and $R$. pulmo showed a comparable protein content while a lower protein content was assessed in $C$. tuberculata (Table 1). Previous experiments using lyophilized jellyfish showed the release of proteinaceous compounds in the PBS medium $[12,13]$. Similarly, using fresh jellyfish we observed leakage of soluble proteins in the PBS medium after HT100 or control treatment at $25^{\circ} \mathrm{C}$. The homogenates, HT100-treated or control jellyfish samples, separated by centrifugation in Soluble Fraction (supernatant) and Insoluble Fraction (pellet) were analyzed for protein content. The release of proteinaceous compounds in PBS by WB A. coerulea specimens seems independent from the temperature, because no significant differences in the content of soluble and insoluble protein were observed between control and HT100 treatments (Fig. 6A A $_{1}$. The protein content of the jellyfish body parts after the heat treatments were also separately analyzed (Fig. $6 \mathrm{~A}_{2}-\mathrm{A}_{3}$ ). Following HT100 of the $A$. coerulea umbrella, the content of soluble and insoluble protein in the homogenates were significantly higher ( $p=0.012$, and $p=0.013$, respectively) than in control specimens. Conversely, HT100 of A. coerulea oral arms as compared to controls resulted in a significant decrease of the soluble and insoluble protein contents $(p=0.01$ and $p=0.02$, respectively). In parallel, the amount of proteins released from HT100-exposed oral arms slightly increased in the HT100 medium ( $p=0.04)$. Such opposite effects of HT100 on jellyfish U and OA parts may depend on their different internal anatomies and tissue composition, with the solid U containing a thick extracellular matrix (mesoglea) mainly composed of fibrillar protein (i.e., collagen) whereas the protein content of the delicate OA may be largely referable to the epithelial cell layers and a thinner mesoglea. Overall, when WB homogenates of the whole jellyfish were analysed, the opposite effect of HT100 on the two body parts was not detectable anymore. However, due to the prominent biomass of the A. coerulea $\mathrm{U}$ part compared to the OA, the potential exploitation of this species could be envisaged on the jellyfish as a whole.

HT100 significantly affected the protein content in the jellyfish $C$. tuberculata, known to establish a successful endosymbiotic association with photosynthetic dinoflagellates (zooxanthellae). A significant decrease of protein content in soluble $(p=0.02)$ and insoluble $(p=0.01)$ fractions of the WB (whole jellyfish) was detected (Fig. 6 $\mathrm{B}_{1}$ ), although no significant differences were detected in the proteinaceous compounds released in the medium. The slight increase $(p=0.01)$ of protein released in the aqueous medium at HT100 was mainly due to the OA than to the U body part (Fig. $6 \mathrm{~B}_{2}-\mathrm{B}_{3}$ ). Most likely the proteinaceous material belongs to the thermal-sensitive zooxanthellae endosymbionts, which leaked from the OA jellyfish endodermal tissue during HT100. Both soluble and insoluble proteins from the $\mathrm{U}$ part, and soluble proteins from $\mathrm{OA}$, decreased significantly ( $p=0.04, p=0.01$, and $p=0.01$, respectively) in the HT100 specimens, while a slight but significant $(p=0.01)$ increase of insoluble proteins in the HT100 OA, as compared to controls. This was likely due to a denaturation and precipitation in insoluble form of the main protein components of $C$. tuberculata OA.

Differently from the other two species, WB specimens of $R$. pulmo apparently do not release any proteinaceous compounds in the aqueous medium at both control and HT100 treatments; also, a very low but significant reduction $(p=0.012)$ of soluble proteins was detected after the HT100 (Fig. 6C $_{1}$ ). When the body parts were separately processed, marked differences were evident among samples derived from $\mathrm{U}$ and $\mathrm{OA}$ body parts (Fig. $6 \mathrm{C}_{2}-1 \mathrm{C}_{3}$ ). A slight but significant decrease of protein content in the soluble $(p=0.02)$ and insoluble $(p=0.04)$ fractions of $\mathrm{U}$ 

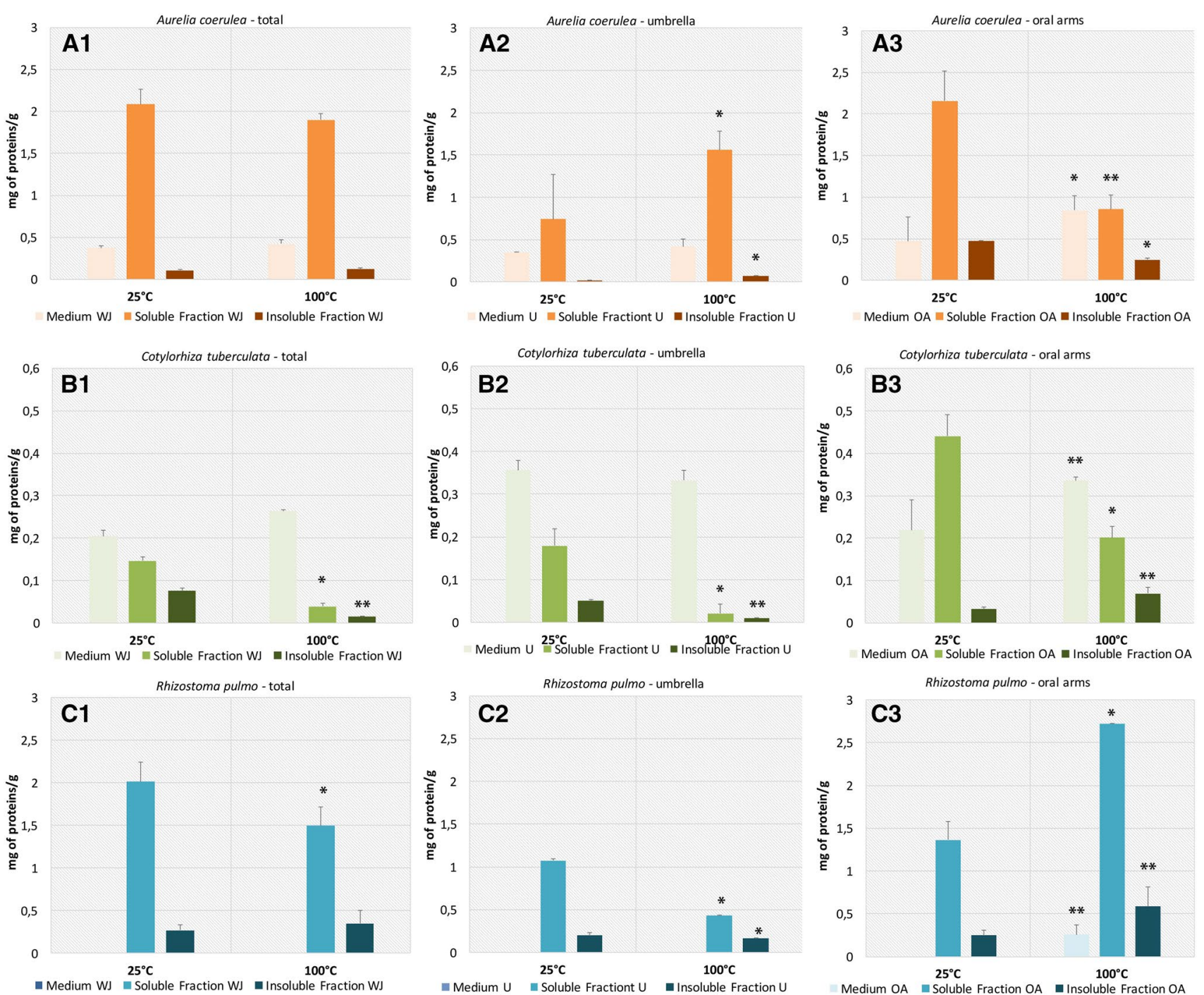

Fig. 6 Protein contents in jellyfish samples ( $W J$ whole jellyfish, $U$ umbrella, $O A$ oral arms) after heat treatment at $25^{\circ} \mathrm{C}$ or $100{ }^{\circ} \mathrm{C}$. a Aurelia coerulea: $\mathrm{A}_{1}=\mathrm{WJ} ; \mathrm{A}_{2}=\mathrm{U} ; \mathrm{A}_{3}=\mathrm{OA}$. Protein content in PBS medium (cream), Soluble Fraction (orange) and Insoluble Fraction (brown). b Cotylorhiza tuberculata: $\mathrm{B}_{1}=\mathrm{WJ} ; \mathrm{B}_{2}=\mathrm{U} ; \mathrm{B}_{3}=\mathrm{OA}$. Protein content in PBS medium (light green), Soluble Fraction (green),

was detected. Conversely, a significant increase of proteinaceous concentration in the soluble $(p=0.02)$ and insoluble $(p=0.01)$ fractions of the OA was observed. In parallel, a weak protein release in the medium was detected after HT100 OA specimens, maybe as result of large production of released mucus (mucopolysaccharides linked to proteins), abundantly produced by this species. The opposite effect of the HT100 on protein contents of U and OA jellyfish parts was not detectable when the whole jellyfish was treated, also because in $R$. pulmo OA have a substantial biomass comparable to that of the large white umbrella. To our knowledge, these results represent the first available information on the effect of heat treatment on the protein content of fresh
Insoluble Fraction (dark green). c Rhizostoma pulmo: $\mathrm{C}_{1}=\mathrm{WJ}$; $\mathrm{C}_{2}=\mathrm{U} ; \mathrm{C}_{3}=\mathrm{OA}$. Protein content in PBS medium (celeste), Soluble Fraction (sky blue), Insoluble Fraction (dark blue). Protein content as mean protein weight $(\mathrm{mg})$ per gram of fresh sample $\pm \mathrm{SD}$, out of three independent experiments ( $15 \leq n \leq 21$ samples). ${ }^{*} p \leq 0.05 ; * * \leq 0.01$; $* * * p \leq 0.001$

jellyfish material. Previous data were obtained only from salted and dehydrated commercial jellyfish stripes, whose texture appeared to be better conserved by heat treatment at $80{ }^{\circ} \mathrm{C}$ for $10 \min [54,55]$.

\section{Effect of heat treatment on phenolic content}

The Folin-Ciocalteu assay is an analytical method used to determine the content of total phenolic compounds validated for many complex extracts and the obtained value is directly comparable and informative among various samples. The Folin-Ciocalteu reagent is a specific redox reagent able to react with the available hydroxyl groups present on the 
aromatic ring of the phenolic compounds to form a blue complex that can be quantified by visible-light spectrophotometry. This assay is mainly used for plant extracts notoriously rich in simple and complex phenolic compounds and is here used to quantify the possible presence of phenolic molecules with potential antioxidant activity. Phenolic compounds were found in fresh samples of all the three Mediterranean jellyfish, confirming our previous results related to phenols found in hydro-alcoholic extracts [13] and in lyophilized samples [12]. At our knowledge, there is no previous available information about phenols in fresh samples of jellyfish. Therefore, the nature and origin of phenols in the three jellyfish species are currently under investigation in our laboratory. Here we report on changes of content of phenolic compounds induced by heat treatment. As for protein, the determination of total phenols of the three jellyfish species following HT100 and control treatments shows the presence of an overall higher phenolic content in A. coerulea and $R$. pulmo compared to C. tuberculata (Fig. 7). Phenolic compounds in the whole $A$. coerulea are released in the medium in comparable amounts at both control and HT100 treatments (Fig. $7 \mathrm{~A}_{1}$ ). Heating of WB A. coerulea caused only a significant declining of total phenols found in the soluble fraction $(p=0.01)$, while no significant differences between the insoluble fractions treated at the two temperatures were found. A similar trend was detectable for the soluble fractions when umbrella (U) and oral arms (OA) were treated separately (Fig. $7 \mathrm{~A}_{2}-\mathrm{A}_{3}$ ). Compared to the control
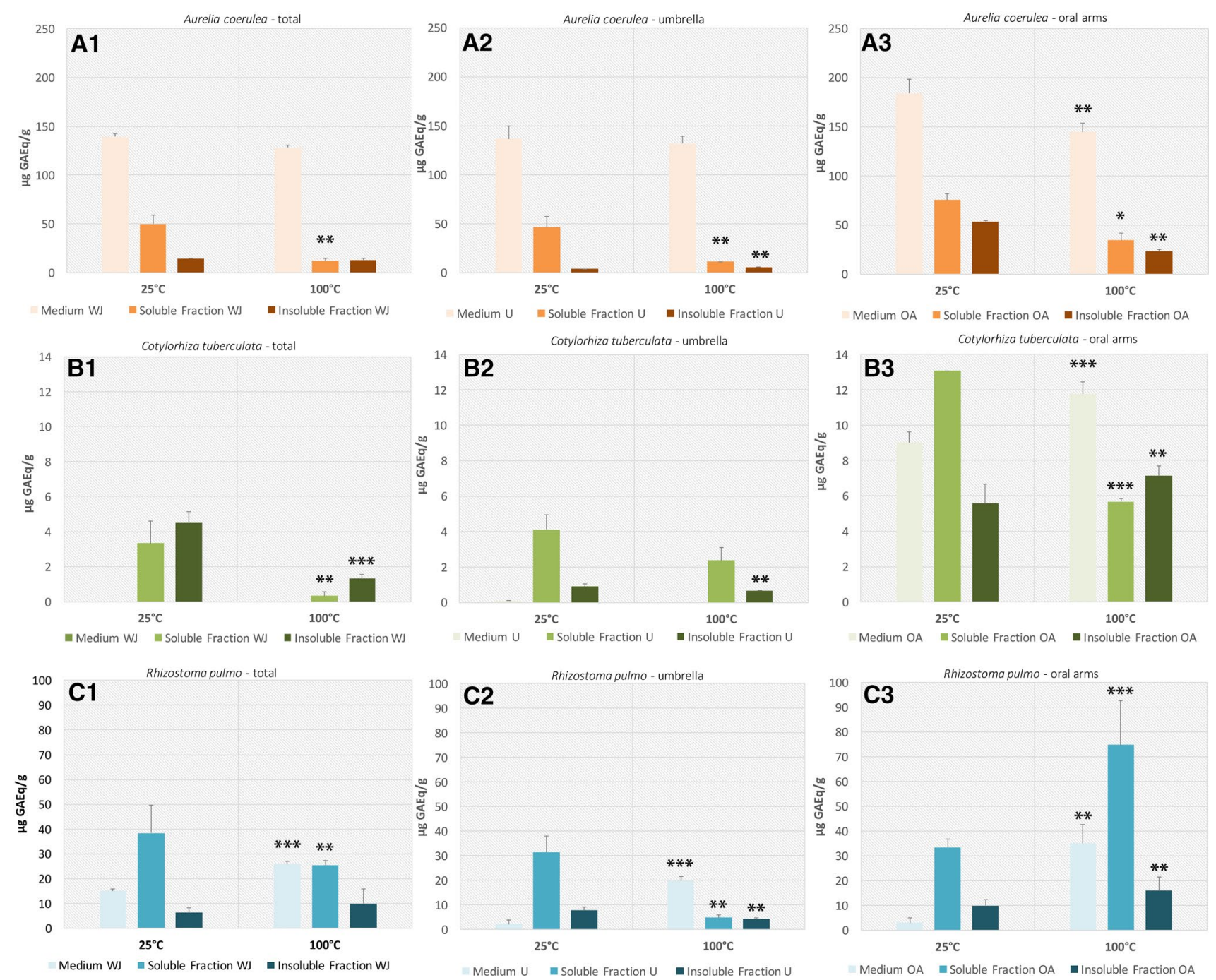

Fig. 7 Total phenolic content (TPC) in jellyfish samples ( $W J$ whole jellyfish, $U$ umbrella, $O A$ oral arms) after heat treatment at $25^{\circ} \mathrm{C}$ or $100{ }^{\circ} \mathrm{C}$. a Aurelia coerulea: $\mathrm{A}_{1}=\mathrm{WJ} ; \mathrm{A}_{2}=\mathrm{U} ; \mathrm{A}_{3}=\mathrm{OA}$. TPC in PBS medium (cream colour), Soluble Fraction (orange) and Insoluble Fraction (brown). b Cotylorhiza tuberculata: $\mathrm{B}_{1}=\mathrm{WJ}$; $\mathrm{B}_{2}=\mathrm{U} ; \mathrm{B}_{3}=\mathrm{OA}$. TPC in PBS medium (light green), Soluble Frac- tion (green), Insoluble Fraction (dark green). c Rhizostoma pulmo: $\mathrm{C}_{1}=\mathrm{WJ} ; \mathrm{C}_{2}=\mathrm{U} ; \mathrm{C}_{3}=\mathrm{OA}$. TPC in PBS medium (celeste), Soluble Fraction (sky blue), Insoluble Fraction (dark blue). TPC expressed as mean value $(\mu \mathrm{g})$ of gallic acid equivalents (GAE) per gram of fresh sample $\pm \mathrm{SD}$, out of three independent experiments $(15 \leq n \leq 21)$. ${ }^{*} p \leq 0.05 ; * * p \leq 0.01 ; * * * p \leq 0.001$ 
treatment, HT100 induced slight changes of total phenolic content $(p=0.01)$ in the insoluble fractions from $\mathrm{U}$ and from OA, in which phenols increased or decreased, respectively. HT100 of OA also caused a significantly reduced $(p=0.01)$ phenolic content detected in the aqueous medium compared to control treatment (Fig. $7 \mathrm{~A}_{3}$ ).

Following control and HT100 treatments of the WB $C$. tuberculata jellyfish or the $\mathrm{U}$ part, the phenolic content in the medium remained unaltered (Fig. $7 \mathrm{~B}_{1}, \mathrm{~B}_{2}$ ). A higher content of phenolic compounds in $\mathrm{OA}$ as compared to $\mathrm{U}$ was assessed. Indeed, the thermal processing of the isolated $\mathrm{OA}\left(\right.$ Fig. $7 \mathrm{~B}_{2}-\mathrm{B}$ ) resulted in the release of phenolic compounds in the medium, mainly from the OA that significantly increased at HT100 as compared to control treatment $(p=0.001)$. As for the protein, this was likely related to the abundant release of symbiotic dinoflagellates from the cut edge of OA and the leakage of their phenolic compounds in the medium. In the WB (whole jellyfish) and OA homogenates following HT100 (Fig. $7 \mathrm{~B}_{1}, \mathrm{~B}_{3}$ ) the amount of phenols in the soluble fractions significantly decreased $(p=0.002$ and $p=0.001$, respectively), but increased in the insoluble fractions ( $p=0.001$ and $p=0.009$, respectively).

Again, a different behavior related to the HT100 treatment on phenolic content was detected for R. pulmo samples (Fig. $7 \mathrm{C}_{1}-\mathrm{C}_{3}$ ). Compared to control, HT100 treatment of the WB samples caused a significant increase $(p=0.0009)$ of the phenolic content in the medium, a decrease in the WB soluble fraction $(p=0.003)$, and no change in the phenolic content of the insoluble fraction. (Fig. $7 \mathrm{C}_{1}$ ). The same trend of increased phenols in the medium was found when the $\mathrm{U}$ $(p=0.0007)$ and OA $(p=0.002)$ body parts were exposed to HT100 (Fig. $7 \mathrm{C}_{2}-\mathrm{C}_{3}$ ). In both soluble and insoluble fractions from HT100 U samples the phenolic content decreased $(p=0.002)$, whereas it increased significantly in soluble $(p=0.0008)$ and insoluble $(p=0.003)$ fractions from HT100 OA samples (Fig. $7 C_{1}$ ). As previously suggested [12], interspecific differences of stiffness and consistency of jellyfish mesoglea may depend on polyphenolic concentration, which may regulate the biophysical properties of collagen-rich layers, such as the jellyfish mesoglea, by influencing the crosslink structure of collagen fibers [56, 57]. Our results suggest the HT100 treatment can affect the jellyfish structural proteins such as collagen, modifying their solubility and ability to interact with phenolic compounds. The high amount of collagen [12] and maybe other contractile proteins, related to striated and smooth muscular cells $[58,59]$, are likely responsible of the different sensitivities of the $\mathrm{U}$ and $\mathrm{OA}$ body parts to the HT100 thermal treatment.

\section{Effect of heat treatment on antioxidant activity}

Antioxidant activity (AA) represents a measure of the nutritional functionality of foods, linked to their underlying potential benefits on health. The relationship between dietary antioxidants and the prevention of diseases related to oxidative stress, cancer prevention, and aging are known, as well as it is known that the bioactivity could be mainly affected by temperature $[45,60,61]$. The measure of the total antioxidant potential, although it is a not specific activity, represent a relevant screening tool for investigating the relationship between dietary antioxidants and their potential in food quality and functionality. Among the various analytical methods developed for measuring the total antioxidant capacity of food and beverages, the TEAC assay [13], based on the ABTS cation radical (ABTS•+) scavenging ability, was used here since it is one of the more effective in aqueous solution.

Thus, we investigated the effect of the HT100 thermal treatment on the AA of soluble and insoluble fractions of the three jellyfish species as whole organisms or body parts. The jellyfish AA was measured in the same samples considered for protein and phenols content, i.e., whole jellyfish (WB) as well as jellyfish body parts separated as umbrella (U) and oral arms (OA) of A. coerulea (Fig. 8), C. tuberculata (Fig. 9), and R. pulmo (Fig. 10), exposed to HT100 compared to control treatment at $25{ }^{\circ} \mathrm{C}$. The chemical nature of the possible antioxidant compounds is still unknown; therefore, for best comparison, the AA was expressed as nmol of Trolox Equivalents per grams of fresh sample (Figs. 8a, 9a, 10a), or per grams of proteins (Figs. 8b, 9b, 10b) or per phenolic content (GAE) (Figs. 8c, 9c, 10c).

Overall, AA was detectable in almost all samples (HT100-treated and non-treated controls) of the three jellyfish species (Figs. 8, 9, 10). The highest AA resulted in fresh samples of Rhizostoma pulmo, with R. pulmo $\geq$ C. tuberculata $>>$ A. coerulea, confirming our previous data obtained from lyophilized samples [12].

HT100 differently affected the AA detected in the diverse jellyfish species, as well as in the different anatomical parts and the different fractions. The AA was higher in OA as compared to the U samples. Although AA was affected by HT100 in some way, generally it never completely lost.

Compared to controls, HT100 treatment on the WB (whole jellyfish) specimens of A. coerulea caused a significant decrease of AA in both soluble and insoluble fractions and in the PBS medium (Fig. $8 \mathrm{~A}_{1}, \mathrm{~B}_{1}, \mathrm{C}_{1}$ ). The greatest AA was detectable in soluble and insoluble fractions of $\mathrm{OA}$ (Fig. $8 \mathrm{~A}_{3}, \mathrm{~B}_{3}, \mathrm{C}_{3}$ ), which, however, represent a minor component of $A$. coerulea biomass. The release in the medium of antioxidant compounds from the $\mathrm{U}$ and $\mathrm{OA}$ samples was also detectable, with OA $>$ U. HT100 affected the antioxidant capacity of compounds mainly occurring in the insoluble fraction of both $\mathrm{U}$ and OA samples. Likely, both protein and phenols contributed to the recorded AA (Fig. 8b, c).

Also, the jellyfish C. tuberculata, either as WB and isolated $\mathrm{U}$ and $\mathrm{OA}$ samples, released antioxidant compounds 

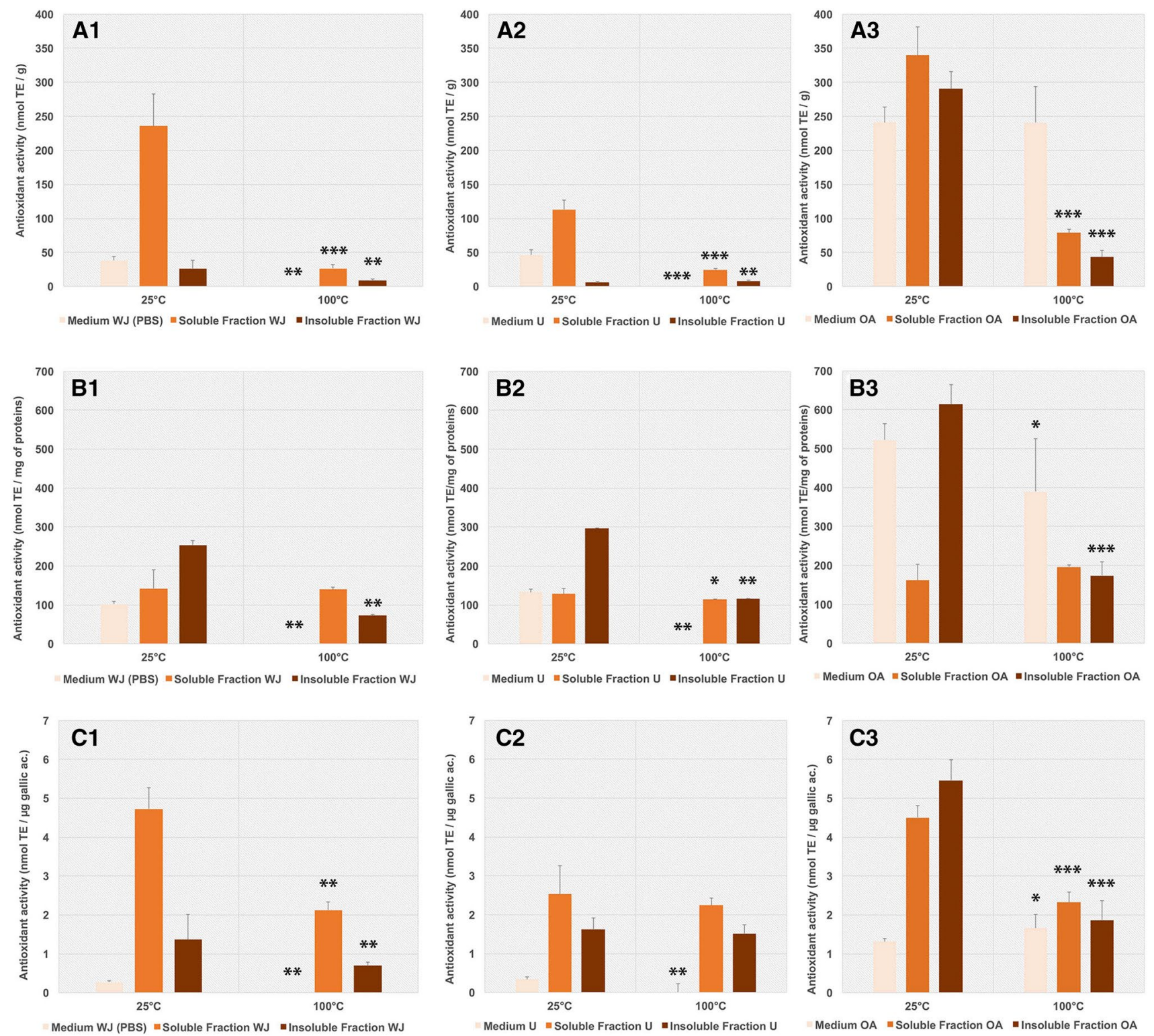

Fig. 8 Total antioxidant activity in jellyfish samples of Aurelia coerulea (WJ whole jellyfish, $U$ umbrella, $O A$ oral arms) after heat treatment at $25{ }^{\circ} \mathrm{C}$ or $100{ }^{\circ} \mathrm{C}$. Total antioxidant activity in PBS medium (cream colour), soluble fraction (orange) and insoluble fraction (brown), expressed either as mean values (nmol) of Trolox Equiva-

in the medium in both control and HT100 treatments. Compared to controls, HT100 of WB specimens did apparently not induce changes in the detectable AA in the medium; conversely, HT100 of U samples induced a significant increase $(p=0.002)$ of AA in medium, while HT100 of OA caused a AA decrease $(p=0.0008)$ in the medium. As previously noted, proteins were the main compounds detected in the medium of WB and U samples of C. tuberculata (Fig. 6), while high content of phenols can be found in the medium of OA samples (Fig. 7). Thus, we can infer the observed AA can be attributed to both classes of compounds. This lents (TE) per gram of fresh weight $\left(\mathrm{A}_{1-3}\right)$, or per $\mathrm{mg}$ of proteins $\left(B_{1-3}\right)$, or per total phenols $(\mu \mathrm{g}$ of $\mathrm{GAE})\left(\mathrm{C}_{1-3}\right)$. Three independent experiments $(15 \leq n \leq 21)$ were performed. ${ }^{*} p \leq 0.05 ; * * p \leq 0.01$; $* * * p \leq 0.001$

is also confirmed considering the AA referred to protein and to phenolic content showed in Fig. $9 \mathrm{~B}_{1-3}$ and $\mathrm{C}_{1-3}$. The HT100 treatment significantly reduced the AA in the soluble fraction of WB jellyfish $(p=0.0006)$ as well as in the separated $\mathrm{U}$ samples $(p=0.002)$ (Fig. $\left.9 \mathrm{~A}_{1-2}\right)$ while no change was detected in soluble fraction of OA samples (Fig. $9 \mathrm{~A}_{3}$ ). The AA detected in insoluble fraction of $C$. tuberculata seemed to be poorly affected by the HT100 treatment (Fig. 9A $\mathrm{A}_{1}$ ) while a significant increase of AA (referred to total weight) appeared in the insoluble fraction from the isolated $\mathrm{U}(p=0.001)$ and OA samples $(p=0.002)\left(\right.$ Fig. $\left.9 \mathrm{~A}_{2-3}\right)$. 

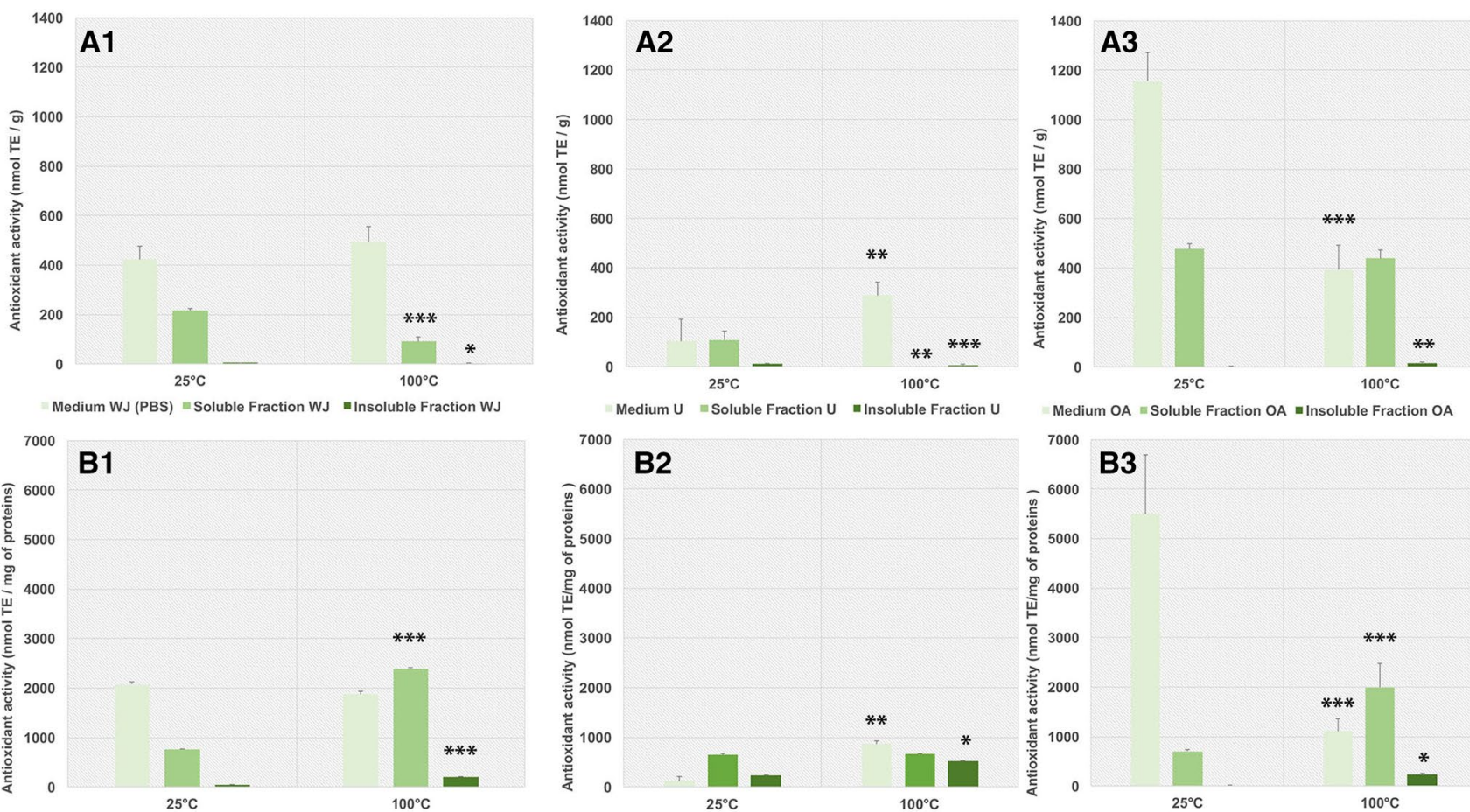

Medium WJ (PBS) $=$ Soluble Fraction WJ *Insoluble Fraction WJ
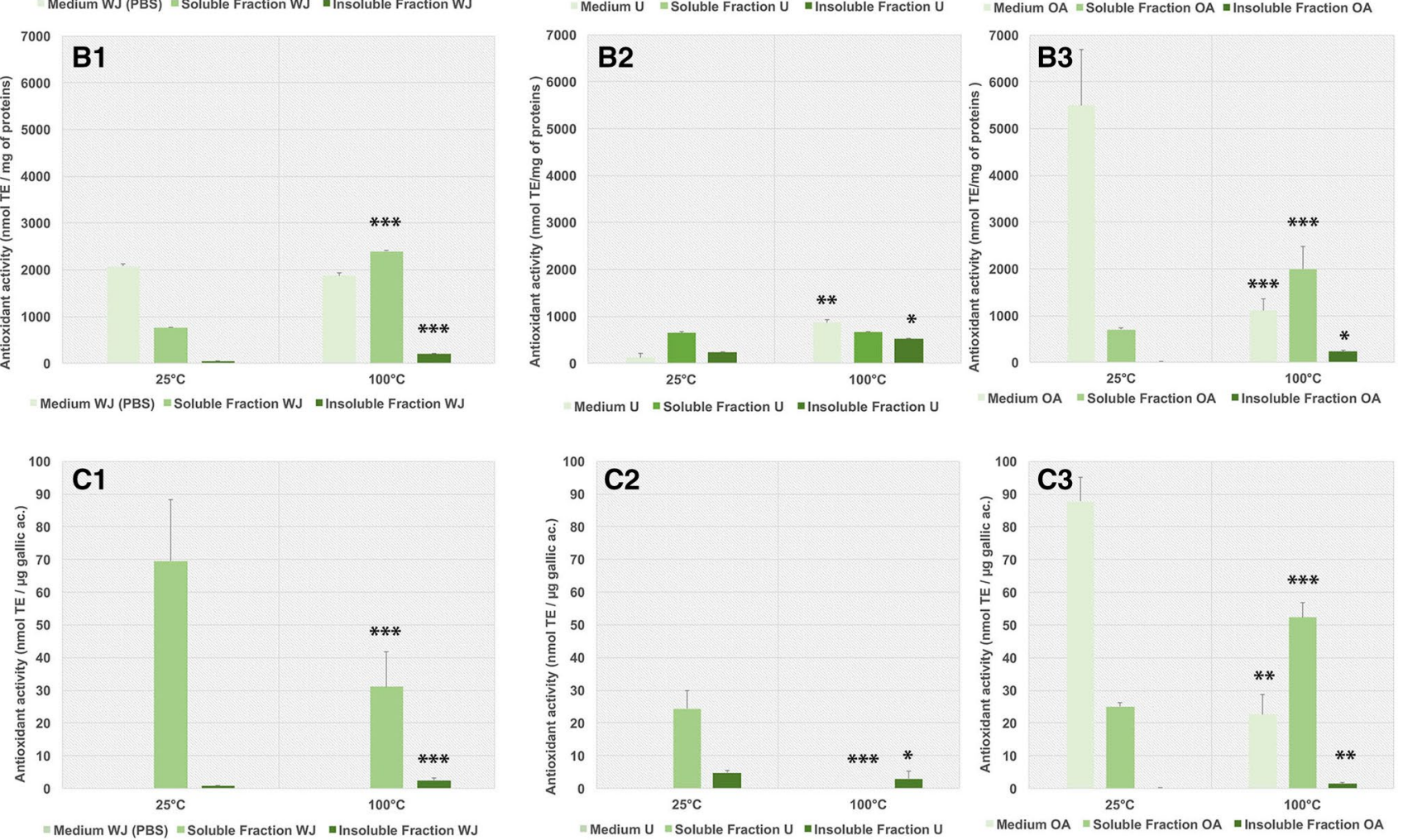

Fig. 9 Total antioxidant activity in jellyfish samples of Cotylorhiza tuberculata (WJ whole jellyfish, $U$ umbrella, $O A$ oral arms) after heat treatment at $25{ }^{\circ} \mathrm{C}$ or $100{ }^{\circ} \mathrm{C}$. Total antioxidant activity in PBS medium (light green), Soluble Fraction (green) and Insoluble Fraction (dark green), expressed either as mean values (nmol) of Trolox

Data of antioxidant activity referred to proteins or phenolic content (Fig. 9B $\mathrm{B}_{1}, \mathrm{C}_{1}$ ) show significant differences, likely reflecting differences in the content of antioxidant proteinaceous or phenolic compounds, respectively. Overall, data from $C$. tuberculata samples indicated that the HT100 negatively affects AA in WB jellyfish and $U$ fractions, increased $\mathrm{AA}$ in the $\mathrm{OA}$ fractions, as a result of their diverse content of protein, phenols or other antioxidant compounds. Data expressed in reference to total weight as well as to protein and phenolic contents were similar (Fig. 9 $\mathrm{A}_{2-3}, \mathrm{~B}_{2-3}, \mathrm{C}_{2-3}$ ). It can be hypothesized that this effect can be due to (1) thermal-induced structural changes making the proteinaceous or
Equivalents (TE) per gram of fresh weight $\left(\mathrm{A}_{1-3}\right)$, or per mg of proteins $\left(B_{1-3}\right)$, or per total phenols ( $\mu$ g of GAE) $\left(C_{1-3}\right)$. Three independent experiments $(15 \leq n \leq 21)$ were performed. $* p \leq 0.05 ; * * \leq 0.01$; $* * * p \leq 0.001$

not-proteinaceous antioxidant compounds more available, and (2) to the denaturation of carotenoid-protein complexes with the release of antioxidants, such as peridinin [13].

Differently of the other two jellyfish species, but consistently with results gathered from analysis of protein content, in R. pulmo no release of antioxidant compounds was detectable in the aqueous medium (PBS) from both control and HT100 treatments of WB jellyfish samples (Fig. 10). This result indirectly identifies protein as the main antioxidant compound in $R$. pulmo. Remarkably, the HT100 treatment did not significantly affect the AA detected in soluble and insoluble fractions from the WB 

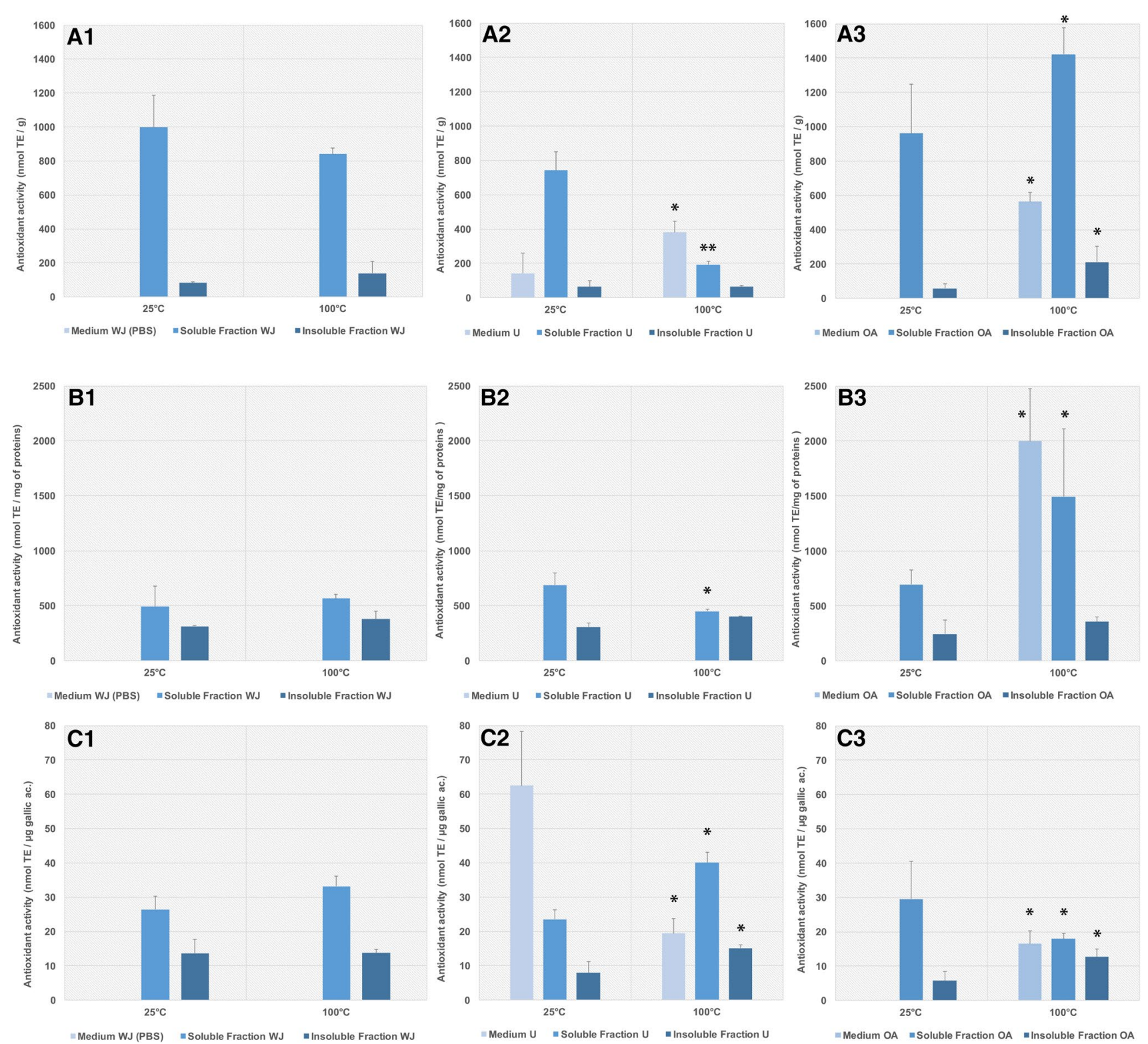

Fig. 10 Total antioxidant activity (AA) in jellyfish samples of Rhizostoma pulmo (WJ whole jellyfish, $U$ umbrella, $O A$ oral arms) after heat treatment at $25{ }^{\circ} \mathrm{C}$ or $100{ }^{\circ} \mathrm{C}$. Total antioxidant activity in PBS medium (celeste), Soluble Fraction (sky blue) and Insoluble Fraction (dark blue), expressed either as mean values (nmol) of Trolox

samples (Fig. $10 \mathrm{~A}_{1}, \mathrm{~B}_{1}, \mathrm{C}_{1}$ ). When $\mathrm{U}$ and $\mathrm{OA}$ samples were treated separately, the AA detected in the medium increased by control and HT100 treatments of U samples, with a significant increase in HT100-treated U samples $(p=0.02)$, or by the HT100 treatment of OA samples $(p=0.014)$. This effect was likely due to leakage of antioxidant compounds, mainly of phenolic nature, from the tissues (Fig. $10 \mathrm{~A}_{2-3}, \mathrm{~B}_{2-3}, \mathrm{C}_{2-3}$ ). Antioxidant activity in the soluble fraction of HT100-treated U samples, significantly decreased $(p=0.01)$, but increased $(p=0.026)$ in
Equivalents (TE) per gram of fresh weight $\left(\mathrm{A}_{1-3}\right)$, or per $\mathrm{mg}$ of proteins $\left(\mathrm{B}_{1-3}\right)$, or per total phenols $\left(\mu \mathrm{g}\right.$ of GAE) $\left(\mathrm{C}_{1-3}\right)$. Three independent experiments $(15 \leq \mathrm{n} \leq 21)$ were performed. $* p \leq 0.05 ; * * \leq 0.01$; $* * * p \leq 0.001$

HT100-treated OA samples. In the insoluble fractions, AA was not affected by HT100 in U samples while increased $(p=0.015)$ in OA (Fig. $\left.10 \mathrm{~A}_{2-3}\right)$. The detected pattern of changes in AA values parallels the pattern of modification of protein and phenolic content. This suggests that both types of compounds can be responsible of AA. In particular, considering the AA values referred to protein or phenolic content, they seem related to protein rather phenolic compounds, although these latter are very abundant in R. pulmo. 
Overall, the HT100 of $R$. pulmo, as WB samples, does not negatively affect the jellyfish antioxidant properties. Instead, the HT100 treatment of $R$. pulmo OA samples induced a significant and surprising increase of AA, a result strikingly different from the other two investigated jellyfish species, which should be taken in consideration in the potential food processing design.

Overall, a strong relationship between the presence of high amounts of phenolic compounds and high AA was identified. It is likely that additional compounds, such as carotenoids produced by symbiotic dinoflagellates or other molecules of still unknown structure, can contribute to the measured AA.

Our data confirm previous reports on the antioxidant activity of jellyfish [32-35, 62]. In addition, Yu et al. [43] reported radical scavenging activity in protein fractions of tentacles of Rhopilema esculentum, with higher AA activity at increased temperature in the range of $20-80{ }^{\circ} \mathrm{C}$.

Proteins isolated from both Asiatic or Mediterranean jellyfish have a strong radical scavenging activity and reducing power [12, 35, 42, 63-65]. CcTrx 1, a member of the evolutionary conserved family of thioredoxin Trx proteins, with roles in the protection against oxidative stress and cell redox regulation, was identified found to be constitutively expressed in all tested body parts, including umbrella and oral arms, of the Atlantic jellyfish Cyanea capillata [66]. Likely such antioxidant proteins may work as endogenous mechanisms for reactive oxygen species (ROS) removal and maintain the intracellular environment in a reduced state. Marine organisms are continuously exposed to biotic and abiotic stressors, including global climate change, which may result in an overproduction of ROS and sub-lethal impacts on growth and reproduction [67]. In this framework, beyond the nutritional potential of jellyfish biomasses, radical scavenging proteins in jellyfish tissues could represent natural antioxidant resources, with potential nutraceutical value. Those natural antioxidants constitute a broad range of compounds including phenolic compounds, nitrogen-containing compounds and carotenoids. Eventually, the occurrence of phenolic compounds in jellyfish, as well as symbiotic association with photosynthetic dinoflagellates, increase the diversity of molecular mechanisms of antioxidant activity in jellyfish tissues, and highlight the potential for further added value in jellyfish biomass exploitation.

The radical scavenging activity of jellyfish compounds may represent the underlying mechanism assigning curative properties to jellyfish ingredients for bronchitis, tracheitis, gastric ulcer, and asthmas as reported by the Chinese food therapy [26]. Future studies on the specific antioxidant mechanisms could clarify specific causal relationship.

\section{Conclusions}

This work introduces a simple and proven method to process jellyfish that loom as a new biomass potentially useful as human food in European Countries. One of the main issues that prevents the jellyfish exploitation as food in western countries is the absence of a safe and quick processing method able to assure stabilization and good quality of the final product.

In this work, we reported for the first time the effect of a thermal treatment on jellyfish biomass as possible first processing step, targeting to the use of jellyfish either as food or food ingredient. Here it is shown that the hightemperature treatment (HT100: $100{ }^{\circ} \mathrm{C}, 10 \mathrm{~min}$ ) induces changes in the protein and phenolic content in the biomass of three of the most common and potentially edible Mediterranean jellyfish species, and this process is compatible with a mild food processing. The HT100 treatment does not reduce and, in some cases, it may even increase the radical scavenging properties of edible or potentially edible jellyfish. Further investigations are needed to clarify the molecular basis of the radical scavenging activity of jellyfish tissues, however that property labeling them as a new, largely available and sustainable functional novel food. The differences observed among the three Mediterranean jellyfish indicate that a thermal treatment is particularly suitable for the processing of the species $R$. pulmo, since its exposure to thermal treatment at $100{ }^{\circ} \mathrm{C}$ leads to stabilization of jellyfish protein content and to an increased antioxidant activity. This confirms the intuition of S. Macrì, the first zoologist who first described this species in 1778 [68]. Finally, the reduction of the biomass volume, together with a first microbiological stabilization, make the thermal treatment as a possible first step towards a new, "Western style" jellyfish food processing.

This minimal processing could be the base of knowledge for diverse stakeholders, such as fishery operators, food industry, and consumers that ultimately would lead to develop a new marketable product.

Acknowledgements The authors gratefully acknowledge Ms Jennifer Jiang, sales and marketing general manager of Simplot China/Hong Kong/Tai Wan/Macao, for updated reference about jellyfish production in China (Chenjin, 2017. China Fishery Statistical Yearbook). The Authors also thanks Mr. Leone D’Amico for his valuable technical support.

Funding This work was supported by the European Union's Horizon 2020 programme GO-JELLY - A gelatinous solution to plastic pollution - under grant agreement no. 774499; CERES (Climate Change and European Aquatic Resources, grant n. 678193); MED-JELLYRISK (Project N. I-A/1.3/098); and Italian Regional Programme POR Puglia FSE 2007-2013 - Ritorno al Futuro - call n. 19/2009. 


\section{Compliance with ethical standards}

Conflict of interest The authors declare no conflict of interest.

Compliance with ethics requirements All applicable international, national, and institutional guidelines for the care and use of animals were followed by the authors.

Open Access This article is distributed under the terms of the Creative Commons Attribution 4.0 International License (http://creativeco mmons.org/licenses/by/4.0/), which permits unrestricted use, distribution, and reproduction in any medium, provided you give appropriate credit to the original author(s) and the source, provide a link to the Creative Commons license, and indicate if changes were made.

\section{References}

1. Brotz L, Pauly D (2017) Studying jellyfish fisheries: toward accurate national catch reports and appropriate methods. In: Mariottini GL (ed) Jellyfish: ecology, distribution patterns and human interactions. US Nova Publishers, New York, pp 313-329

2. Kitamura M, Omori M (2010) Synopsis of edible jellyfishes collected from Southeast Asia, with notes on jellyfish fisheries. Plankton Benthos Res 5(3):106-118. https://doi.org/10.3800/ pbr.5.106

3. Gibbons MJ, Boero F, Brotz L (2016) We should not assume that fishing jellyfish will solve our jellyfish problem. ICES J Mar Sci 73(4):1012-1018. https://doi.org/10.1093/icesjms/fsv255

4. Hsieh YHP, Leong FM, Rudloe J (2001) Jellyfish as food. Hydrobiologia 451:11-17. https://doi.org/10.1023/A:1011875720415

5. Brotz L, Schiariti A, López-Martínez J, Álvarez-Tello J, Peggy Hsieh YH, Jones RP et al (2017) Jellyfish fisheries in the Americas: origin, state of the art, and perspectives on new fishing grounds. Rev Fish Biol Fish 27(1):1-29. https://doi.org/10.1007/ s11160-016-9445-y

6. Hsieh Y-HP, Rudloe J (1994) Potential of utilizing jellyfish as food in Western countries. Trends Food Sci Technol 5(7):225-229. https://doi.org/10.1016/0924-2244(94)90253-4

7. Omori M, Nakano E (2001) Jellyfish fisheries in southeast Asia. Hydrobiologia 451:19-26. https://doi.org/10.1023/A:1011879821 323

8. FAOSTAT (Food and Agriculture Organization of the United Nations Statistics Division) (2017) FAO yearbook: fishery and aquaculture statistics. 2015. FAO Annu Yearb. https://doi. org/10.5860/CHOICE.50-5350

9. Chenjin (2017) China Statistical yearbook of Marine fisheries. Beijing. (in Chinese)

10. EU Regulation 2015/2283 of 25/11/2015 http://eur-lex.europa.eu/ eli/reg/2015/2283/oj

11. D'Amico P, Leone A, Giusti A, Armani A (2017) Jellyfish and humans: not just negative interactions. In: Mariottini GL (ed) Jellyfish: ecology, distribution patterns and human interactions. US Nova Publishers, New York, pp 331-352

12. Leone A, Lecci R, Durante M, Meli F, Piraino S (2015) The bright side of gelatinous blooms: nutraceutical value and antioxidant properties of three mediterranean jellyfish (Scyphozoa). Mar Drugs 13(8):4654-4681. https://doi.org/10.3390/md13084654

13. Leone A, Lecci RM, Durante M, Piraino S (2013) Extract from the zooxanthellate jellyfish Cotylorhiza tuberculata modulates gap junction intercellular communication in human cell cultures. Mar Drugs 11(5):1728-1762. https://doi.org/10.3390/md11051728
14. Li J, Hsieh Y-HP (2004) Traditional Chinese food technology and cuisine. Asia Pac J Clin Nutr 13(2):147-155. http://www.ncbi. nlm.nih.gov/pubmed/15228981

15. Sloan NA, Gunn CR (1985) Fishing, processing, and marketing of the jellyfish, Aurelia aurita (L.), from southern British Columbia. Can Ind Rep Fish Aquat Sci 157:1-29

16. Huang YA (1988) Cannonball jellyfish (Stomolophus meleagris) as a food resource. J Food Sci 53(2):341-343. https://doi. org/10.1111/j.1365-2621.1988.tb07701.x

17. Ogimoto M, Suzuki K, Haneishi N, Kikuchi Y, Takanashi M, Tomioka N et al (2016) Aluminium content of foods originating from aluminium-containing food additives. Food Addit Contam Part B Surveill 9(3):185-190. https://doi.org/10.1080/19393 210.2016.1158210

18. Aguilar F, Autrup H, Barlow S, Castle L, Crebelli R, Dekant W et al (2008) Scientific opinion of the panel on food additives, flavourings, processing aids and food contact materials on a request from European commission on safety of aluminum from dietary intake. EFSA J 754:1-34

19. Zhang H, Zhang JY, Wang HL, Luo PJ, Zhang JB (2016) The revision of aluminum-containing food additive provisions in China. Biomed Environ Sci BES 29(6):461-466. https://doi. org/10.3967/bes2016.061

20. Raposo A, Coimbra A, Amaral L, Gonçalves A, Morais Z (2018) Eating jellyfish; safety, chemical and sensory properties. J Sci Food Agric 98(10):3973-3978

21. Wright NT, Humphrey JD (2002) Denaturation of collagen via heating: an irreversible rate process. Annu Rev Biomed Eng 4:109-128. https://doi.org/10.1146/annurev.bioeng.4.10100 1.131546

22. Wang W, Zhang Y, Ye R, Ni Y (2015) Physical crosslinkings of edible collagen casing. Int J Biol Macromol 81:920-925. https ://doi.org/10.1016/J.IJBIOMAC.2015.09.032

23. Pearson AM, Gillett TA (1999) Processed meats. Springer Science \& Business Media, Sep 30, 1996-Technology \& Engineering-448 pages Aspen Publishers. https://books.google.it/ books/about/Processed_Meats.html?id=SJhrqEuJoRIC\&redir _esc $=\mathrm{y}$. Accessed 22 May 2018

24. Skipnes D (2014) Heat processing of fish. In: Seafood processing: technology, quality and safety. Wiley, Hoboken, pp 61-81. https://doi.org/10.1002/9781118346174.ch4

25. Yu TY, Morton JD, Clerens S, Dyer JM (2017) Cookinginduced protein modifications in meat. Compr Rev Food Sci F 16:141-159. https://doi.org/10.1111/1541-4337.12243

26. Zou P (2016) Traditional Chinese medicine, food therapy, and hypertension control: a narrative review of Chinese literature. Am J Chin Med 44(08):1579-1594. https://doi.org/10.1142/ S0192415X16500889

27. Sila A, Bougatef A (2016) Antioxidant peptides from marine by-products: Isolation, identification and application in food systems. A review. J Funct Foods 21:10-26. https://doi. org/10.1016/J.JFF.2015.11.007

28. Zhang Q, Song C, Zhao J, Shi X, Sun M, Liu J et al (2018) Separation and characterization of antioxidative and angiotensin converting enzyme inhibitory peptide from jellyfish gonad hydrolysate. Molecules 23(1):94. https://doi.org/10.3390/molec ules23010094

29. Addad S, Esposito JY, Faye C, Ricard-Blum S, Lethias C (2011) Isolation, characterization and biological evaluation of jellyfish collagen for use in biomedical applications. Mar Drugs 9(6):967983. https://doi.org/10.3390/md9060967

30. Barzideh Z, Latiff AA, Gan C, Alias AK (2014) ACE inhibitory and antioxidant activities of collagen hydrolysates from the ribbon Jellyfish (Chrysaora sp.). Food Technol Biotecnol 52(4), 495-504. https://doi.org/10.17113/b.52.04.14.3641 
31. Zhuang Y, Sun L, Zhang Y, Liu G (2012) Antihypertensive effect of long-term oral administration of jellyfish (Rhopilema esculentum) collagen peptides on renovascular hypertension. Mar Drugs 10(2):417-426. https://doi.org/10.3390/md10020417

32. Ding JF, Li YY, Xu JJ, Su XR, Gao X, Yue FP (2011) Study on effect of jellyfish collagen hydrolysate on anti-fatigue and antioxidation. Food Hydrocolloids 25(5):1350-1353. https://doi. org/10.1016/j.foodhyd.2010.12.013

33. Morais ZB, Pintao AM, Costa IM, Calejo MT, Bandarra NM, Abreu P (2009) Composition and in vitro antioxidant effects of jellyfish Catostylus tagi from Sado estuary (SW Portugal). J Aquat Food Prod T 18(1-2):90-107. https://doi.org/10.1080/10498 850802581799

34. Yu HH, Liu XG, Xing RE, Liu S, Guo ZY, Wang PB et al (2006) In vitro determination of antioxidant activity of proteins from jellyfish Rhopilema esculentum. Food Chem 95(1):123-130. https:// doi.org/10.1016/j.foodchem.2004.12.025

35. Zhuang Y, Hou H, Zhao X, Zhang Z, Li B (2009) Effects of collagen and collagen hydrolysate from jellyfish (Rhopilema esculentum) on mice skin photoaging induced by UV Irradiation. J Food Sci 74(6):H187-H188. https://doi.org/10.111 $1 / \mathrm{j} .1750-3841.2009 .01236 . x$

36. Aluko RE (2015) Amino acids, peptides, and proteins as antioxidants for food preservation. In: Handbook of antioxidants for food preservation. Elsevier, Amsterdam, pp 105-140. https://doi. org/10.1016/B978-1-78242-089-7.00005-1

37. Elias RJ, Kellerby SS, Decker EA (2008) Antioxidant activity of proteins and peptides. Crit Rev Food Sci Nutr 48(5):430-441. https://doi.org/10.1080/10408390701425615

38. Leone A, Longo C, Trosko JE (2012) The chemopreventive role of dietary phytochemicals through gap junctional intercellular communication. Phytochem Rev 11(2-3):285-307. https://doi. org/10.1007/s11101-012-9235-7

39. Ramos S (2008) Cancer chemoprevention and chemotherapy: Dietary polyphenols and signalling pathways. Mol Nutr Food Res 52(5):507-526. https://doi.org/10.1002/mnfr.200700326

40. Rosillo MA, Alarcón-de-la-Lastra C, Sánchez-Hidalgo M (2016) An update on dietary phenolic compounds in the prevention and management of rheumatoid arthritis. Food Funct 7(7):2943-2969. https://doi.org/10.1039/C6FO00485G

41. Loo G (2003) Redox-sensitive mechanisms of phytochemicalmediated inhibition of cancer cell proliferation. J Nutr Biochem 14(2):64-73. https://doi.org/10.1016/S0955-2863(02)00251-6

42. Zhuang Y, Sun L, Zhao X, Wang J, Hou H, Li B (2009) Antioxidant and melanogenesis-inhibitory activities of collagen peptide from jellyfish (Rhopilema esculentum). J Sci Food Agric 89:17221727. https://doi.org/10.1002/jsfa.3645

43. Yu H, Liu X, Xing R, Liu S, Li C, Li P (2005) Radical scavenging activity of protein from tentacles of jellyfish Rhopilema esculentum. Bioorg Med Chem Lett 15(10):2659-2664. https://doi. org/10.1016/j.bmcl.2005.03.044. PMID: 15863337

44. Montgomery L, Seys J, Mees J (2016) To pee, or not to pee: a review on envenomation and treatment in European jellyfish species. Mar Drugs 14:127. https://doi.org/10.3390/md14070127

45. Wilcox CL, Yanagihara AA (2016) Heated debates: hot-water immersion or ice packs as first aid for cnidarian envenomations? Toxins 8(4):97. https://doi.org/10.3390/toxins8040097

46. Amaral L, Raposo A, Morais Z, Coimbra A (2018) Jellyfish ingestion was safe for patients with crustaceans, cephalopods, and fish allergy. Asia Pac Allergy 8(1):e3. https://doi.org/10.5415/apall ergy.2018.8.e3

47. Scorrano S, Aglieri G, Boero F, Dawson MN, Piraino S (2017) Unmasking Aurelia species in the Mediterranean sea: an integrative morphometric and molecular approach. Zool J Linn Soc 18:243-267. https://doi.org/10.1111/zoj.12494
48. Bradford MM (1976) A rapid and sensitive method for the quantitation of microgram quantities of protein utilizing the principle of protein-dye binding. Anal Biochem 72(1-2):248-254. https:// doi.org/10.1016/0003-2697(76)90527-3

49. Singleton VL, Rossi JA (1965) Colorimetry of total phenolics with phosphomolybdic-phosphotungstic acid reagents. Am J Enol Vitic $16: 144-158$

50. R Core Team (2017) R: A language and environment for statistical computing. Vienna

51. Canty A, Ripley B (2017) boot: Bootstrap R (S-plus) Functions. package version 1.3-20

52. Davison AC, Hinkley DV (1997) Bootstrap methods and their application. Cambridge University Press, Cambridge. http://statw ww.epfl.ch/davison/BMA/

53. Subhan F, Ikram M, Shehzad A, Ghafoor A (2015) Marine Collagen: an emerging player in biomedical applications. J Food Sci Technol 52:4703-4707. https://doi.org/10.1007/s1319 7-014-1652-8

54. Kimura H, Mizuno H, Saito T, Suyama Y, Ogawa H, Iso N (1991) Structural change of salted jellyfish during cooking. Nippon Suisan Gakk 57(1):85-90

55. Poole S, Edwards J, Naidoo R (2002) Creating a shelf stable marinated jellyfish product from the underutilised species Catostylus mosaicus. Available: http://frdc.com.au/Archived-Reports/ FRDC\%20Projects/1998-417-DLD.pdf

56. Vidal CMP, Leme AA, Aguiar TR, Phansalkar R, Nam JW, Bisson J, McAlpine JB, Chen SN, Pauli GF, Bedran-Russo A (2014) Mimicking the hierarchical functions of dentin collagen crosslinks with plant derived phenols and phenolic acids. Langmuir 30:14887-14993. https://doi.org/10.1021/1a5034383

57. Madhan B, Subramanian V, Rao JR, Nair BU, Ramasami T (2005) Stabilization of collagen using plant polyphenol: role of catechin. Int J Biol Macromol 37:47-53. https://doi.org/10.1016/j.ijbio mac.2005.08.005

58. Chapman DM (1999) Microanatomy of the bell rim of Aurelia aurita (Cnidaria: Scyphozoa). Can J Zool 77(1):34-46. https:// doi.org/10.1139/z98-193

59. Leclère L, Röttinger E (2017) Diversity of Cnidarian muscles: function, anatomy, development and regeneration. Front Cell Dev Biol 4:157. https://doi.org/10.3389/fcell.2016.00157

60. Diplock AT (1994) Antioxidants and disease prevention. Mol Aspects Med 15(4):293-376. https://doi.org/10.1016/00982997(94)90005-1

61. Gupta RK, Patel AK, Shah N, Choudhary AK, Jha UK, Yadav UC et al (2014) Oxidative stress and antioxidants in disease and cancer: a review. Asian Pac J Cancer Prev 15(11):4405-4409. https://doi.org/10.7314/APJCP.2014.15.11.4405

62. Mariottini GL, Pane L (2010) Mediterranean jellyfish venoms: a review on scyphomedusae. Mar Drugs 8(4):1122-1152. https:// doi.org/10.3390/md8041122

63. Hu Y, Chen J, Hu G, Yu J, Zhu X, Lin Y et al (2015) Statistical research on the bioactivity of new marine natural products discovered during the 28 years from 1985 to 2012. Mar Drugs 13(1):202-221. https://doi.org/10.3390/md13010202

64. Li R, Yu H, Xing R, Liu S, Qing Y, Li K et al (2012) Isolation, identification and characterization of a novel antioxidant protein from the nematocyst of the jellyfish Stomolophus meleagris. Int J Biol Macromol 51(3):274-278. https://doi.org/10.1016/J.IJBIO MAC.2012.05.015

65. Zhuang Y, Zhao X, Li B (2009) Optimization of antioxidant activity by response surface methodology in hydrolysates of jellyfish (Rhopilema esculentum) umbrella collagen. J Zhejiang Univ Sci B 10(8):572-579. https://doi.org/10.1631/jzus.B0920081

66. Ruan Z, Liu G, Guo Y, Zhou Y, Wang Q, Chang Y et al (2014) First report of a thioredoxin homologue in jellyfish: Molecular cloning, expression and antioxidant activity of CcTrx 1 from 
Cyanea capillata. PLoS One 9(5):e97509. https://doi.org/10.1371/ journal.pone.0097509

67. Lesser MP (2006) Oxidative stress in marine environments: biochemistry and physiological ecology. Annu Rev Physiol 68:253278. https://doi.org/10.1146/annurev.physiol.68.040104.110001

68. Macrì S (1778) Nuove osservazioni intorno la storia naturale del polmone marino degli antichi. Biblioteca Regia Monacensis: Munich, Germany. Available on https://goo.gl/fXimwZ Accessed on April 2018
Publisher's Note Springer Nature remains neutral with regard to jurisdictional claims in published maps and institutional affiliations. 